\title{
Nevşehir İlinde Karayolu Ulaşımından Kaynaklanan Sera Gazı Emisyonlarının Covid-19 Salgını Başlangıç Döneminde Değerlendirilmesi
}

\author{
Hüseyin CÜCE ${ }^{*}$, Oğuzhan UĞUR ${ }^{2}$
}

\section{$\ddot{\mathbf{O z}}$}

Hava kirliliğinin ve sera gazı emisyonlarının etkisi ile birlikte küresel ısınma ve iklim değişikliği uzun süredir dünyanın gündeminde yer almaktadır. Kyoto (1997) ve BM İklim Değişikliği Çerçeve Sözleşmesi kapsamında Paris Anlaşması (COP21, 2015) başta olmak üzere küresel iklimi koruma adına imzalanan protokoller ile üye ülkelerin sera gazı emisyon envanterlerinin oluşturulması ve sera gazı emisyonlarının azaltılması hedeflenmiştir. Bu çalışmada, Nevşehir İli karayolu ulaşımından kaynaklanan sera gazı emisyonlarının $\left(\mathrm{CO}_{2}, \mathrm{CH}_{4}, \mathrm{~N}_{2} \mathrm{O}\right)$ Covid-19 salgını başlangıç döneminde (2020 MartEkim) değerlendirilmesi amaçlanmıştır. Emisyonların hesabında, Hükümetler Arası İklim Değişikliği Paneli (IPCC) kılavuzunda yer alan ve ülkelere önerilen Tier 1 hesaplama metodolojisinden yararlanılmıştır. Hesaplamalarda Nevşehir İl'inde 2015-2020 yılları arasındaki (Mart-Ekim ayları boyunca) yakıt tüketim miktarları esas alınarak sera gazı emisyonları tespit edilmiştir. Sonuçlar benzin, motorin ve LPG akaryakıtlarının yanması sonucu oluşan gazlar dikkate alınarak karbon ayak izi hesabında kullanılan eşdeğer $\mathrm{CO}_{2}$ cinsinden bulunmuştur. Eşdeğer $\mathrm{CO}_{2}$ miktarı Gigagram $(\mathrm{Gg})$ biriminde son 5 yılda sirasiyla, 2015 yılında 255,5 Gg, 2016 yılında 318,2 Gg, 2017 y1lında 453,6 Gg, 2018 y1lında 572,5 Gg, 2019 yılında 346,5 Gg, 2020 yılında 377,0 Gg'dır. Tüm Ülkede olduğu gibi Covid-19 tedbirleri sonucu Nevşehir kent genelinde azalan insan hareketliliği nedeniyle özellikle eşdeğer $\mathrm{CO}_{2}$ emisyonu 2020 yılı Mart-Ekim döneminde geçmiş yılların Mart-Ekim dönemi ortalamasından düşük olduğu görülmüştür.

Anahtar Kelimeler: Sera gazı, Karayolu ulaşımı, Hava kirliliği, İklim değişikliği, Covid-19.

\section{Evaluation of Greenhouse Gas Emissions from Highway Transport in Nevşehir Province in the Beginning Period of the Covid-19 Pandemic}

\begin{abstract}
With the impact of air pollution and greenhouse gas emissions, global warming and climate change have been on the world's agenda for a long time. With the protocols signed for global climate protection, including the Paris Agreement (COP21, 2015) within the scope of Kyoto (1997) and the UN Framework Convention on Climate Change, it is aimed to create greenhouse gas emission inventories and reduce greenhouse gas emissions of the member countries. In this study, it is aimed to evaluate the greenhouse gas emissions $\left(\mathrm{CO}_{2}, \mathrm{CH}_{4}, \mathrm{~N}_{2} \mathrm{O}\right)$ originating from the highway transportation of Nevşehir Province in the beginning period of the Covid-19 epidemic (March-October 2020). Emissions are calculated using the Tier 1 calculation methodology included in the Intergovernmental Panel on Climate Change (IPCC) manual and recommended for countries in the calculation, fuel consumption amounts between the years 2015-2020 (March-October period) in Nevşehir Province were used. The results were found in terms of $\mathrm{CO}_{2}$ equivalent used in the carbon footprint calculation, taking into account the gases formed as a result of the burning of gasoline, diesel and LPG fuels. The equivalent amount of $\mathrm{CO}_{2}$ is $255.5 \mathrm{Gg}$ in $2015,318.2 \mathrm{Gg}$ in $2016,453.6 \mathrm{Gg}$ in $2017,572.5 \mathrm{Gg}$ in $2018,346.5 \mathrm{Gg}$ in 2019 , and $377.0 \mathrm{Gg}$ in 2020. As in the whole country, due to the reduced human mobility in Nevşehir city-wide as a result of the Covid-19 measures, it was observed that the equivalent CO2 emission was lower than the average of the MarchOctober period of previous years in the March-October period of 2020.
\end{abstract}

Keywords: Greenhouse gas, Highway transport, Air pollution, Climate change, Covid-19.

${ }^{1}$ Giresun Üniversitesi, Mühendislik Fakültesi, Harita Mühendisliği Bölümü, Giresun, Türkiye, cucehuseyin@gmail.com
${ }^{2}$ Nevşehir Hacı Bektaş Veli Üniversitesi, Fen Bilimleri Enstitüsü, Çevre Müh. ABD, Nevşehir, Türkiye, oguzhanugur33@gmail.com

${ }^{1}$ https://orcid.org/0000-0002-3590-681X ${ }^{2}$ https://orcid.org/0000-0003-4056-2190 


\section{Giriş}

Hızla artan nüfus; arazi kullanımı, ulusal gelirler ve kalkınma oranlarına göre bölgeden bölgeye değişecek olan enerji, tatlı su, yiyecek ve konut talepleri üzerinde ciddi etkiler yaratmaktadır. Birçok durumda, etkiler en çok stres altındaki bölgelerde, özellikle de gelişmekte olan ülkelerde, ciddi bir şekilde hissedilmektedir. Sürekli ve kontrolsüz emisyonlar nedeniyle insan kaynaklı iklim değişikliği bu etkileri vurgulamaktadır. Sera gazlarının atmosferik konsantrasyonlarındaki artışlar, bu yüzyılın sonunda karşılaşacağımız iklimde geri dönüşü olmayan bir değişime yol açabilir (IPCC, 1990).

Bilim topluluğunda, mevcut oranlarda atmosfere $\mathrm{CO}_{2}$ ve diğer sera gazlarının(metan, azot oksit, ozon ve kloroflorokarbonlar veya CFC'ler) emisyonunun devam etmesinin dünyanın 1sınmasına yol açacağı konusunda fikir birliği vardır (Kreith ve Berger 1999). IPCC'in 2013 yılında yayınladığ rapora göre, küresel ortalama yüzey sıcaklığı 19. yüzyılın sonlarından bu yana artmaktadır (Şekil 1 ve 2).
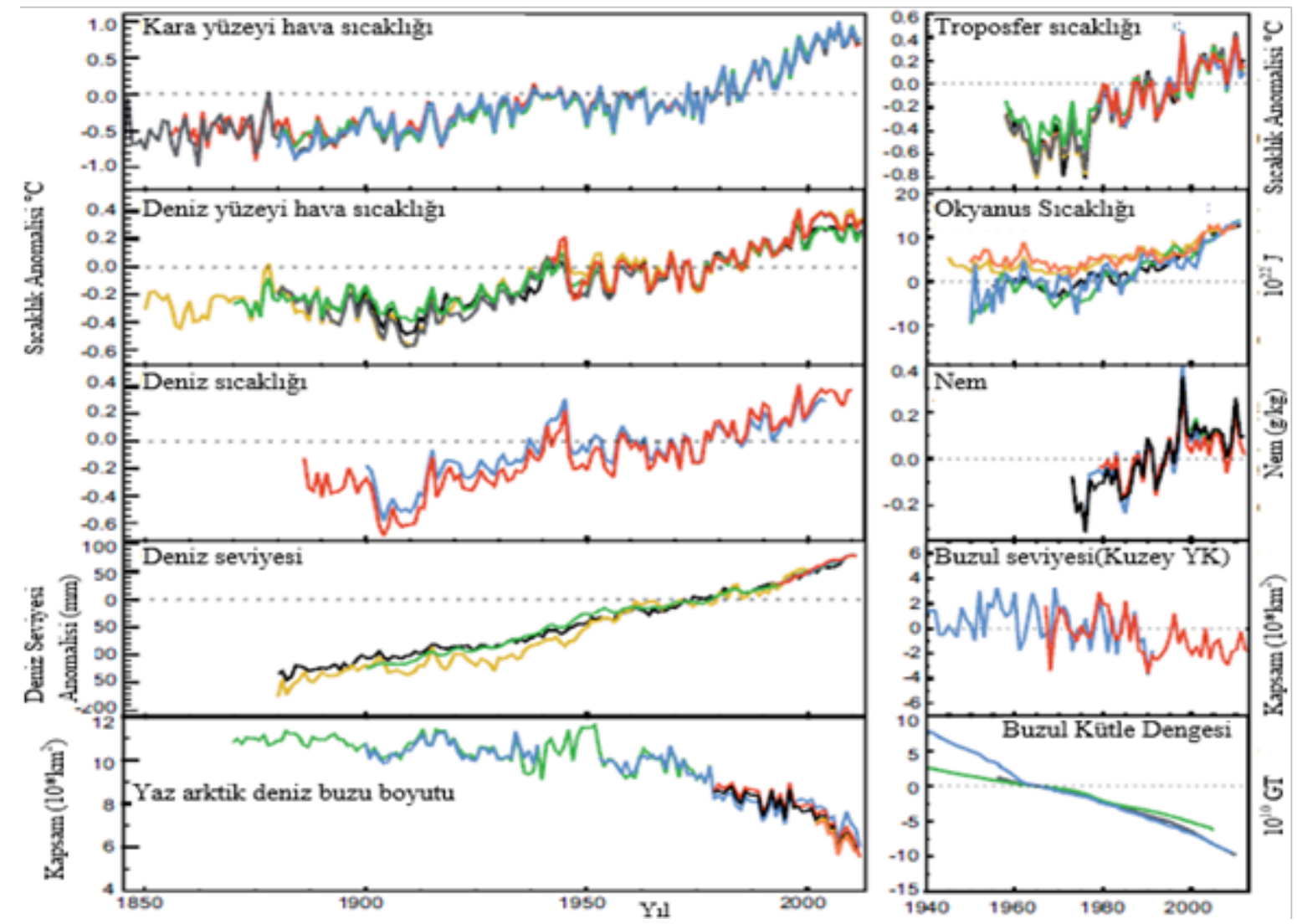

Şekil 1. Değişen küresel iklimin çoklu tamamlayıcı göstergeleri (Change Ipoc, 2007) 


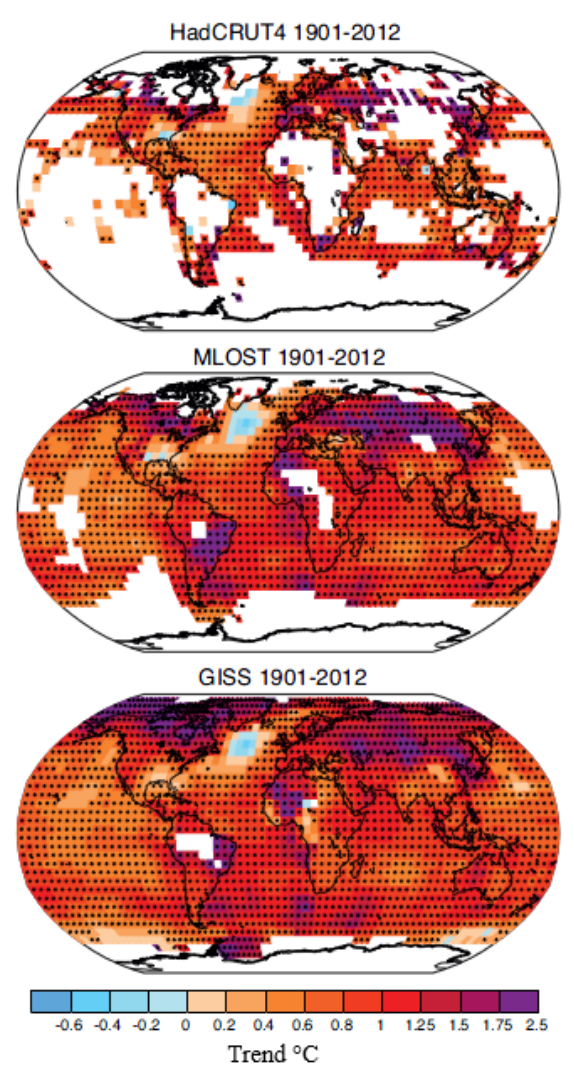

Şekil 2. 1901-2012 yılları arasında yüzey sıcaklık değişimi (IPCC, 2013)

Küresel iklim değişikliği şimdiden dünyanın her bölgesinde ve ekonominin gelecek yıllarda büyümesi beklenen çoğu sektöründe çok çeşitli etkilere yol açmıştır (URL-1). İklim değişikliğinin etkilerinin hafifletilmesi, yalnızca sanayinin hedefleri karşılaması ya da bu hedeflerin ötesine geçmesiyle ilgili değildir. Ulusal, yerel ve bireysel düzeyde de yapılması ve gelecek kuşaklara aktarılması gereken sorumluluklarımız olduğu bir gerçektir. Özellikle kentsel yaşamın konforunu sürdüren insanlar, emisyonları azaltmak için harekete geçmelidir. Şehirler, iklim değişikliğine uyum sağlarken bilgi eksikliği başta olmak üzere birçok zorlukla karşılaşmaktadır. Çoğu şehir yönetimi, şehirlerinin iklim değişikliğinden nasıl etkileneceğini öngörememektedir. İklim değişikliğine hazırlanmak için harekete geçmek isteyen bu şehirler, genellikle nelerin yapılması gerektiğini veya nasıl organize olmak gerektiğini bilmemektedir (Change IPoC, 2007; IPCC, 2013; Mach ve ark., 2016; Cabre ve ark., 2015).

Sera etkisi insanlara ve diğer canlılara yarar sağlayan bir olgu olmasına rağmen sera etkisinin çeşitli nedenlerle artmaya başlaması, özellikle Antarktika başta olmak üzere buzullar üzerindeki etkisi endişe vericidir (Şekil 3). Sera gazları içinde oran olarak en büyüğü su buharıdır ve karbondioksitten çok daha fazla ısı tutma özelliğine sahiptir. Fakat su buharının atmosfer içindeki değişimleri insan faaliyetlerine bağlı değildir (Mercan ve Karakaya, 2013).

Meteorolojik değişimler kent merkezlerinde etkisini aşırı kuraklık ya da sel gibi dramatik biçimlerde doğrudan gösterirken, yerleşim yerlerine uzak noktalarda da dolaylı olarak uzun süreli 
değişimlere sebep olabilmektedir. Örneğin toprak ve bitki örtüsünün yapısını değiştirmesi, hayvan popülasyonlarının azalması veya artması, göç yollarının değişmesi vb. yanı sıra sucul ekosistemlerde de kalıcı kalite değişikliklerin olduğu araştırmacılar tarafından gözlenmiştir (Cüce ve ark., 2020). Bilim insanları iklim değişikliğinin olumsuz etkilerini ortaya koyarak, kaynak kullanım verimliliği üzerine ar-ge çalışmaları ve sürdürülebilir uygulamalar konusunda farklı teknikleri değerlendirmişlerdir (Geçer ve ark., 2019; Dulkadiroğlu, 2018).

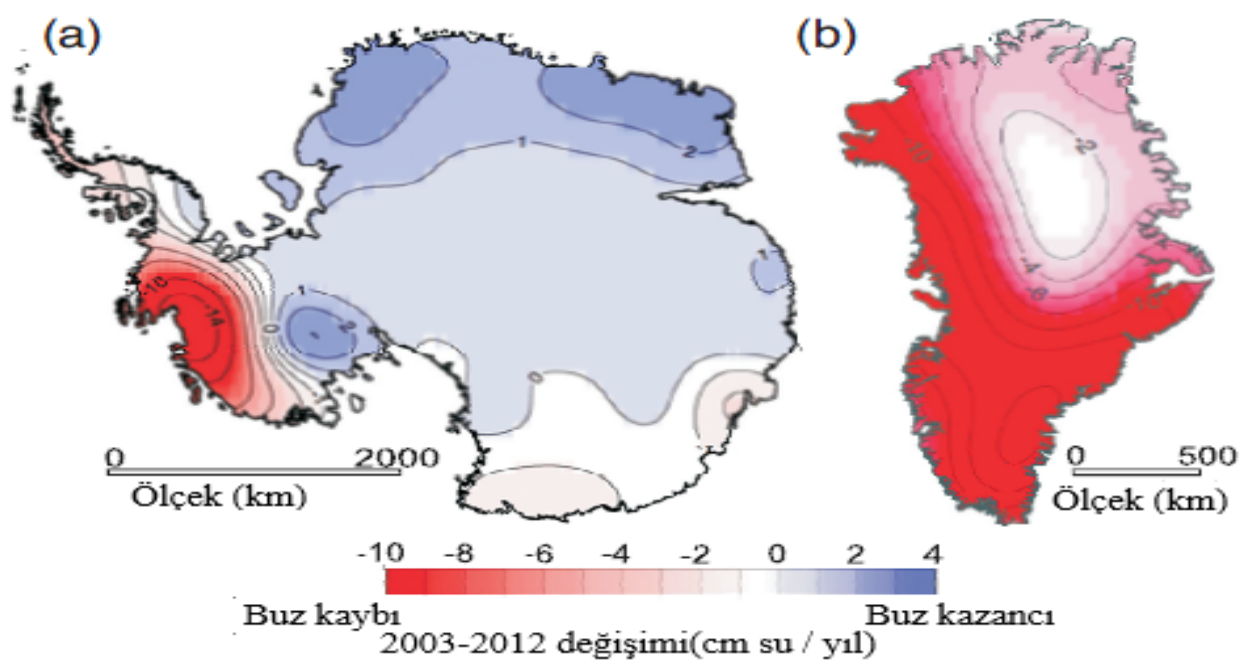

Şekil 3. 2003-2012 yıllarına göre buzul değişimi a: Antartika b: Greenland (IPCC, 2013)

Fosil yakıtların yanması, sera gazı emisyonlarının atmosfere salınmasına katkıda bulunan ana nedenlerden biridir. Fosil yakıtlar aynı zamanda ev, ofis, fabrika ve arabalarda enerji ihtiyacımızı karşılayan, küresel enerji sisteminin ana bileşenlerinden biridir. Fosil yakıtlardan sürdürülebilir, yenilenebilir alternatiflere geçiş kolay olmamakta, tüm enerji sisteminde üretim ve depolamadan dağıtım ve nihai tüketime kadar değişiklik yapılmasını gerektirmektedir (Council, 2009). 


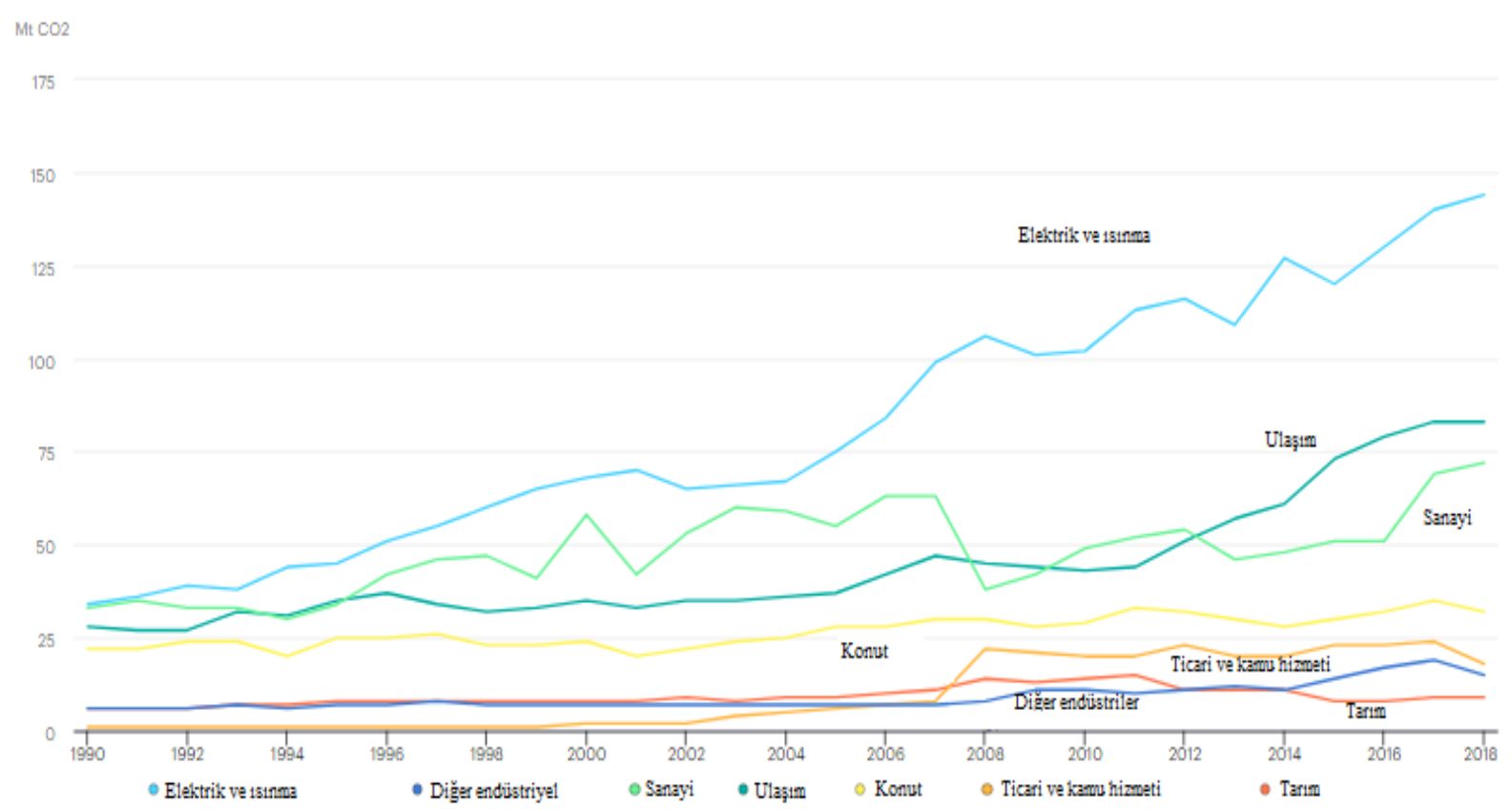

Şekil 4. Türkiye'de sektöre göre $\mathrm{CO}_{2}$ emisyonları 1990-2018 (URL-2)

Şekil 4'de Türkiye'de ulaşım sektörünün $\mathrm{CO}_{2}$ emisyonlarının elektrik ve ısınmadan sonra 2. sırada yer aldığı görülmektedir. Karayolu ulaşımı ise ulaşım sektörünün içinde önemli bir yer almaktadır. Türkiye'de ulaştırma emisyonlarının başlıca kaynağı karayolu taşımacılığıdır. Taşıma emisyonlarının\% 93,0'ını oluşturmaktadır (Canitez 2019; Beken ve ark., 2009). Karayollarını kullanan motorlu taşıtlar, gaz veya partikül halinde bir çok kirleticiyi atmosfere salarlar. $\mathrm{Bu}$ emisyonların karayollarına yakın bölgelerde yer alan toprak ve su yapılarını etkilediği birçok çalışmanın araştırma konusu olmuştur (Demirel ve Ateş, 2018; Kalıpcı ve Başer, 2019). Bu nedenle çevre kalitesinin bozulmasına yol açan ve hava kalitesini ne ölçüde değiştirdiğini görebilmek için bu emisyonların miktarlarını belirlemek envanterini çıkarmak oldukça önemlidir.

Şekil 5 (a)'da siyah çizgi 1970-2019 dönemindeki yıllık ortalama günlük emisyonları, kırmızı çizgi ise Nisan 2020 sonuna kadar tahmin edilen günlük emisyonları göstermektedir. Şekil 5. (b)'de ise 2020 yılında gerçekleşmesi beklenen günlük emisyon miktarları görülmektedir. 

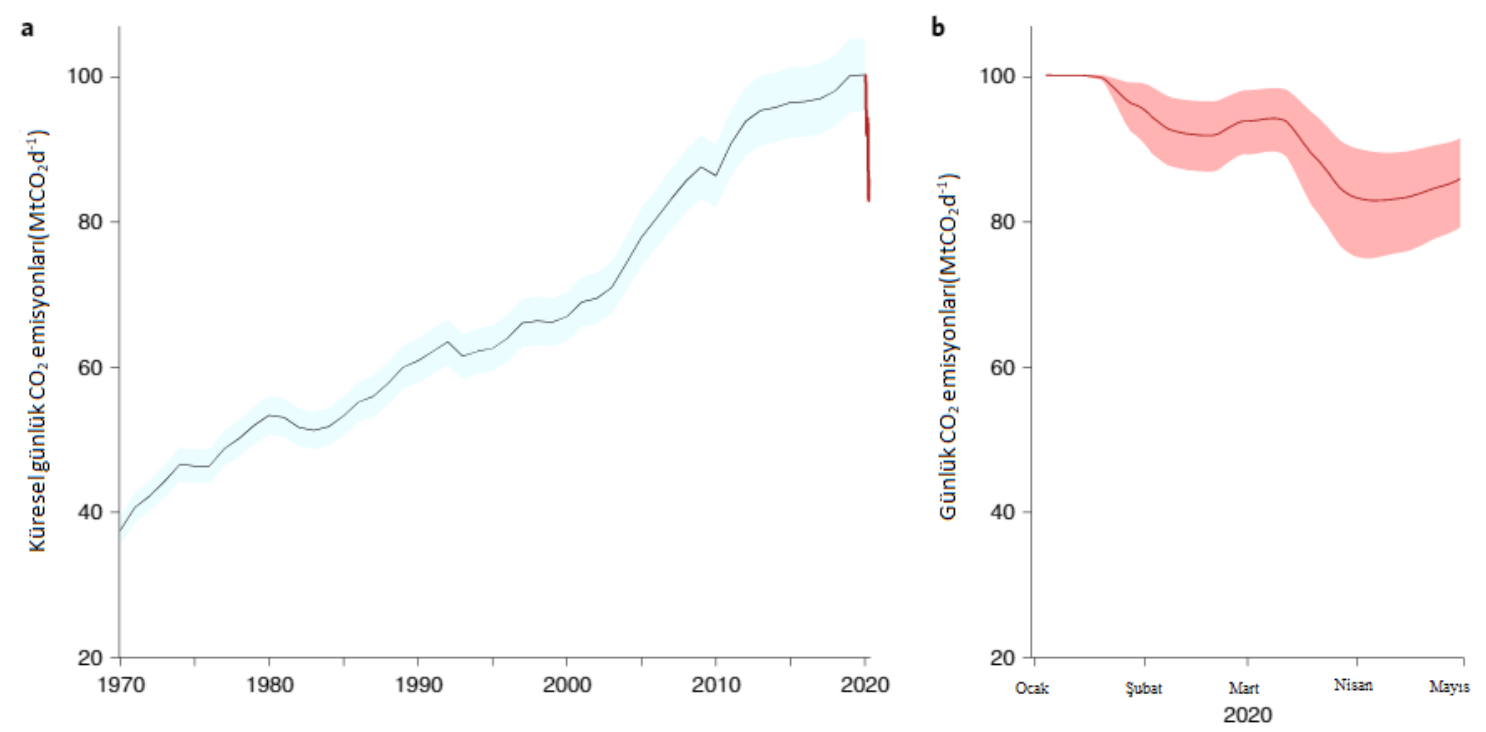

Şekil 5. Küresel günlük fosil kaynaklı $\mathrm{CO}_{2}$ emisyonları (Le Quéré ve ark., 2020)

Ülkeler, sera gazı emisyonunu ve olumsuz etkilerini azaltmak, küresel iklim değişikliğine uyum sağlamak amacıyla protokoller ve anlaşmalar yapmışlardır. Bunlardan en önemli olanları Kyoto Protokolü, Birleşmiş Milletler İklim Değişikliği Çerçeve Sözleşmesi, Paris Anlaşması'dır. Bu protokol ve anlaşmalar ülkelere yükümlülükler getirmekte ve somut adımlar atmalarını sağlamaktadır. Bu somut adımların başında sera gazı emisyon envanteri oluşturmak gelmektedir.

Son bir yıldır Dünya'nın tüm ülkelerinde insan sağlığı ve düzenli yaşamı tehdit eden en büyük tehlike, Corona Virüs Hastalığına neden olan virüs (COVID-19) salgınıdır. COVID-19 virüsü ile enfekte olan çoğu insan genellikle hafif ya da orta derecede solunum yolu hastalı̆̆ yaşar ve çok gelişmiş özel bir tedavi gerektirmeden iyileşmektedir. Yaşlı insanlar ve kardiyovasküler hastalık, diyabet, kronik solunum hastalığı ve kanser gibi tıbbi sorunları olan orta yaşlı insanlarda ciddi hastalık geliştirme ve ölüm olasılığ̣ daha yüksektir (Mitra ve ark., 2020).

Ülkemizde ilk COVİD-19 vakası 11 Mart 2020'de doğrulanmıştır. Eğitim başta olmak üzere birçok alanda önlemler alınmaya başlanmıştır. Uzaktan çalışma teşvik edilmiş ve ekonomik ve sağlık alanında olası şoklara karşı tedbirler genişletilmiştir. Kalabalık ortam ve teması minimuma indirmek için sokağa çıkma kısıtlaması uygulaması, maske takma zorunluluğu gibi toplumun rutin alışkınlıklarının değişmesine yol açan yeni bir döneme geçilmiştir (Ali ve ark., 2020).

Covid-19 pandemi süreci başlarında özellikle Çin gibi kirletici sanayinin yoğun olduğu ülkelerde sanayi alanlarının birkaç ay üretimlerini durdurması bu ülkelerde karbon emisyonun azalması sonucu meteorolojik bulgularla hava kalitesinin artmasına ilişkin veriler ortaya koymuştur (Sancar ve Bostanc1, 2020).

$\mathrm{Bu}$ çalışmada sera gazı emisyon envanterine katkı sağlamak ve daha sonra yapılacak olan çalışmalara farkındalık yaratmak amacıyla Nevşehir İli’nde karayolu ulaşımından kaynaklanan sera 
gazı emisyonlarının Covid-19 salgını başlangıç döneminde yönelimini belirlemek ve olağan tedbirlerin emisyon miktarlarının değişimine etkisini değerlendirmek üzere tipik karbon ayak izi çalışması yapılmıştır. Değerlendirme yapılırken 'Hükümetler Arası İklim Değişikliği Paneli (IPCC)' tarafından belirlenen yöntem ve esaslardan yararlanılmıştır.

\section{Materyal ve Yöntem}

Emisyonlar, tüketilen yakıttan (satılan yakıtla temsil edilir) veya araçların kat ettiği mesafeden tahmin edilebilir. Genel olarak, ilk yaklaşım (satılan yakıt) $\mathrm{CO}_{2}$ için uygundur ve ikincisi (araç türüne ve yol türüne göre kat edilen mesafe) $\mathrm{CH}_{4}$ ve $\mathrm{N}_{2} \mathrm{O}$ için uygundur. $\mathrm{CO}_{2}$ emisyonlarını yakılan yakıtın miktarı ve türü ile karbon içeriğine göre hesaplamak en iyi yöntemdir (Change IPoC, 2006). Karayolu taşımacılığından kaynaklanan emisyonları hesaplamada kullanılan Tier 1, Tier 2 ve Tier 3 olmak üzere 3 farklı yaklaşım vardır. Tier 1 yaklaşımı Tier 2 ve Tier 3'e göre daha az detaylıdır (Şekil 6).

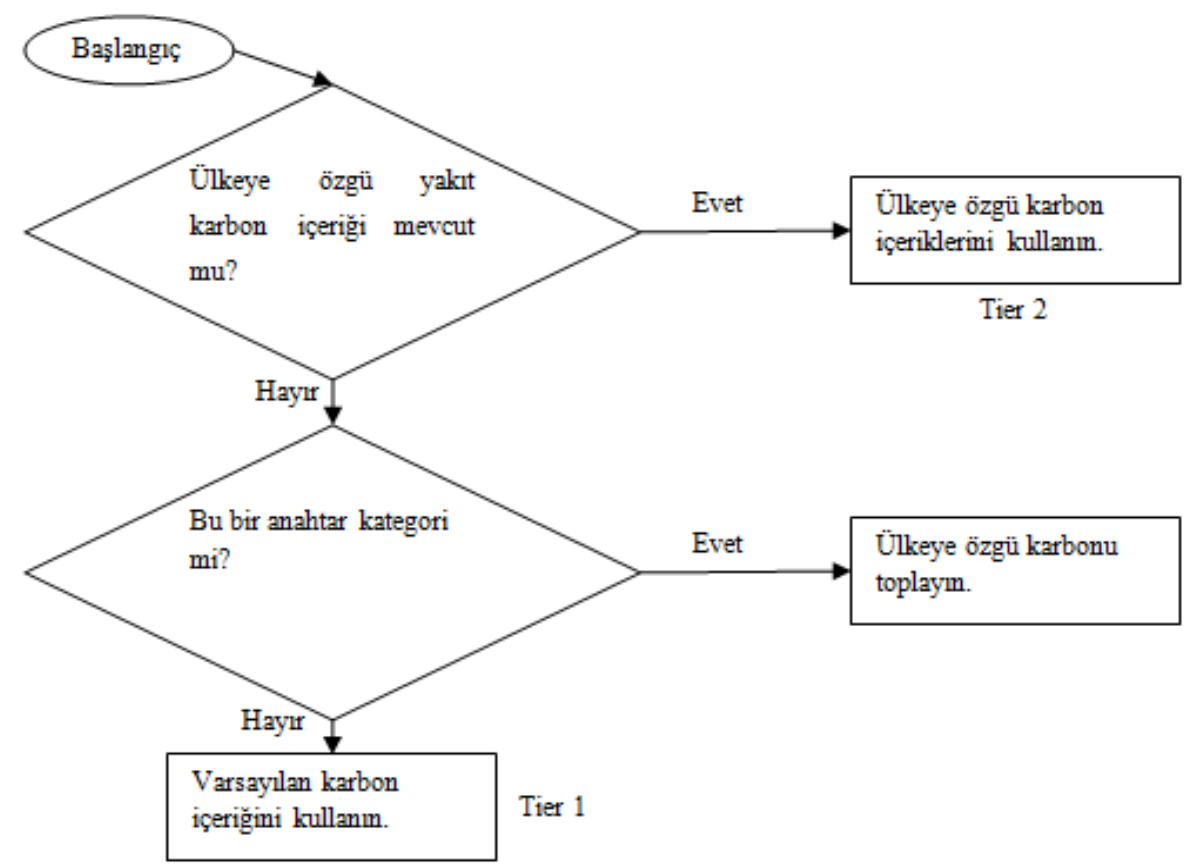

Şekil 6. Karayolu taşımacılığı kaynaklı emisyonları tahmin etme adımları (Change, IPoC, 2006)

Nevşehir İli'nde 2015-2020 yılları arasındaki trafik kaynaklı hava kirliliğini değerlendirmek amacıyla yürütülen bu çalışmada, Covid-19 salgını nedeniyle Türkiye'de alınmaya başlanan tedbirlere esas oluşturması düşüncesiyle, Mart-Ekim dönemi baz alınmıştır. Karayolu ulaşımından kaynaklanan sera gazı emisyonunun değerlendirilmesinde IPCC metodolojisi olan Tier 1 yöntemi kullanılmıştır. Tier 1 yönteminin ihtiyaç duyduğu 2015-2020 Mart-Ekim döneminde Nevşehir İli karayolu taşıtlarının akaryakıt tüketim miktarları kullanılmıştır. Nevşehir İli 2015-2020 Mart-Ekim 
dönemine ait yakıt tüketim miktarları Enerji Piyasası Düzenleme Kurumu’ndan temin edilmiştir. Tier 1 yöntemi diğer yöntemlere göre daha az karmaşık olduğu için seçilmiştir.

Tier 1 için $\mathrm{CO}_{2}, \mathrm{CH}_{4}$ ve $\mathrm{N}_{2} \mathrm{O}$ emisyon hesaplama formülü (Denklem 1);

$$
\text { Emisyon }=\sum\left[\text { Yaklt }_{a} \times E F_{a}\right]
$$

Burada; Emisyon: $\mathrm{CO}_{2}$ emisyon miktarını (kg), Yakıt: Enerji değeri cinsinden yakıt tüketimini (Tj), EF: Emisyon faktörünü, a: Yakıt tipini temsil etmektedir.

IPCC metodolojisine göre yakıt tüketimi Denklem (2) ve Denklem (3) kullanılarak hesaplanmıştır.

Birincil Yaklt Tüketimi $=P_{r}+I_{m}-S_{c}-I_{b}-E_{x}$

İkincil Yakıt Tüketimi $=I_{m}-S_{c}-I_{b}-E_{x}$

Burada; Pr: Üretilen yakıt miktarı, $\mathrm{I}_{\mathrm{m}}$ : İthal edilen yakıt miktarı, $\mathrm{S}_{\mathrm{c}}$ : Stoklarda meydana gelen değişim miktarı, $\mathrm{I}_{\mathrm{b}}$ : Uluslararası kullanıma satılan yakıt miktarı, $\mathrm{E}_{\mathrm{x}}$ : İhraç edilen yakıt miktarlarını gösterir (Change IPoC, 2006).

Her bir yakıt türü için karayolu ulaşımında kullanılan tüketim değerleri (ton) belirlendikten sonra, IPCC Kılavuzundan alınan değerler (TJ/kt cinsinden) ve uygun olan dönüşüm faktörleri (Denklem 4) kullanılarak TJ/Gg değerlerine dönüştürülmüştür.

Enerji Tüketimi [TJ] = Yakıt Tüketimi [t] $\times 10^{-3} \times$ Dönüşüm Faktörü [TJ/Gg]

\section{Bulgular ve Tartışma}

Nevşehir İl geneli yıllık ortalama günlük trafik değerleri (YOGT) Karayolları 6. Bölge Müdürlüğü veri tabanından (URL-3) elde edilmiştir. Araç hacim bilgilerine dayanılarak oluşturulan emisyon haritasında (Şekil 7) araçların akaryakıt türleri eşit kabul edilmiştir. Haritada araç hacim lejantı çok yoğun, yoğun, normal ve az yoğun şeklinde değerlendirilmiştir. Araç hacminin çok yoğun olduğu bölgelerde araç sayısı 10000-19999, yoğun olan bölgelerde araç sayısı 6000-9999, normal olan bölgelerde araç sayısı 3000-5999 ve az yoğun olan bölgelerde araç sayısı 0-2999'dır. 


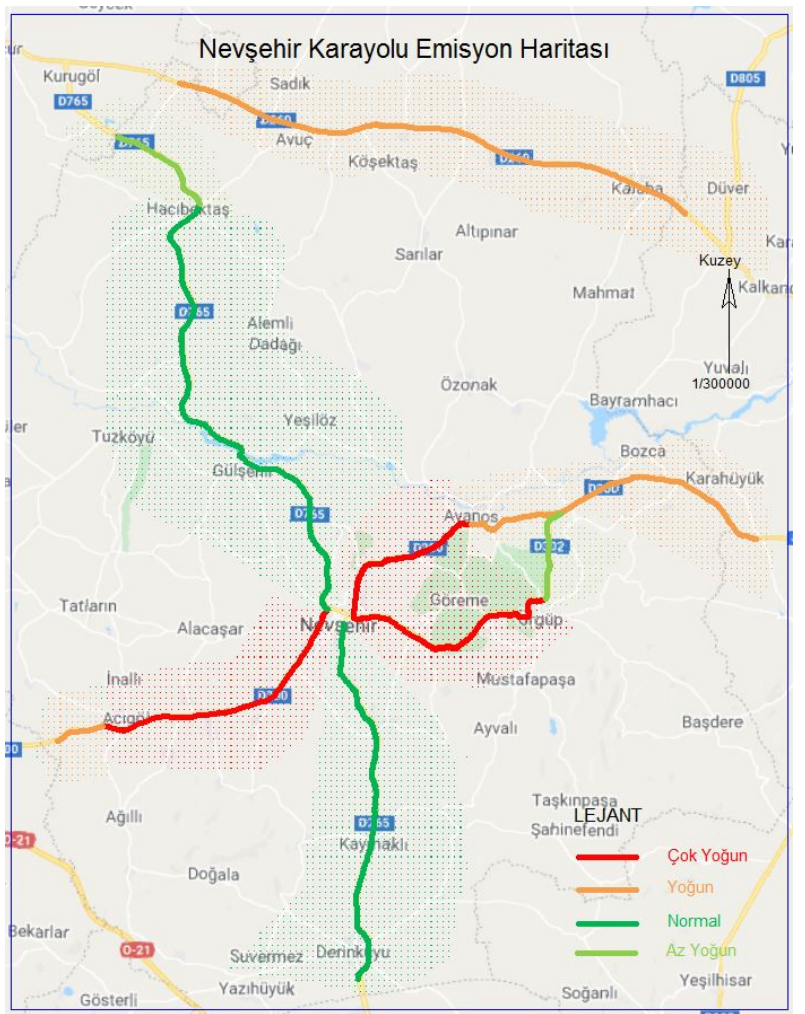

Şekil 7. Nevşehir karayolu araç yoğunluğuna bağlı emisyon haritası (Karayolları 6. Bölge Müdürlüğü 2019 y1lı verilerinden oluşturulmuştur.)

Nevşehir İli'nde 2015-2020 yıllarında Mart ve Ekim aylarını kapsayan dönemler arasında tüketilen benzin, motorin ve LPG yakıtları sonucunda açığa çıkan $\mathrm{CO}_{2}, \mathrm{CH}_{4}$ ve $\mathrm{N}_{2} \mathrm{O}$ miktarları gigagram cinsinden hesaplanmıştır. Eşdeğer karbondioksit değeri, küresel 1sınma potansiyel katsayıları yardımıyla hesaplanmış, metan ve diazotmonoksit gazlarının miktarları karbondioksit eşdeğer cinsinden yazılması sağlanmıştır. Çalışma kapsamında son 5 yıl boyunca oluşan emisyon miktarlarının tüm hesaplamaları Tablo 1-6'da verilmiştir.

Tablo 1. 2015 y1lı Mart-Ekim döneminde emisyon hesap tablosu

\begin{tabular}{|c|c|c|c|c|c|c|c|c|c|}
\hline \multicolumn{10}{|c|}{2015 Yıl1 Mart-Ekim Emisyon Hesap Tablosu } \\
\hline $\begin{array}{c}\mathrm{CO}_{2} \\
\text { Emisyonu }\end{array}$ & $\begin{array}{l}\text { Yakit } \\
\text { Tüketimi } \\
\text { (t) }\end{array}$ & $\begin{array}{l}\text { Değişim } \\
\text { Faktörü } \\
(\mathrm{TJ} / \mathrm{Gg})\end{array}$ & $\begin{array}{c}\text { Enerji Tüketimi } \\
(\mathrm{TJ}) \\
\mathrm{C}=\mathrm{A} \times \mathrm{B} \times 10^{-3}\end{array}$ & $\begin{array}{l}\text { Emisyon } \\
\text { Faktörü } \\
\text { (tC/TJ) }\end{array}$ & $\begin{array}{c}\text { Emisyon İçeriği } \\
(\mathrm{Gg}) \\
\mathrm{E}=\mathrm{C} \times \mathrm{D} \times 10^{-3}\end{array}$ & $\begin{array}{l}\text { Oksitlenme } \\
\text { Yüzdesi } \\
(\%)\end{array}$ & $\begin{array}{c}\text { Emisyon Miktar1 } \\
(\mathrm{Gg}) \\
\mathrm{G}=\mathrm{E} \times \mathrm{F} \times 10^{-3}\end{array}$ & $\begin{array}{c}\text { Küresel Isınma } \\
\text { Potansiyeli }\end{array}$ & $\begin{array}{c}\text { Eşdeğer } \\
\mathrm{CO}_{2} \\
\left(\mathrm{Gg} \mathrm{CO}_{2}\right) \\
\mathrm{I}=\mathrm{G} \times \mathrm{H}\end{array}$ \\
\hline Benzin & 4756 & 44,3 & 210,7 & 18,9 & 18,9 & 0,99 & 14,5 & 1 & 14,5 \\
\hline Motorin & 61184 & 43,0 & 2630,7 & 20,9 & 20,9 & 0,99 & 199,6 & 1 & 199,6 \\
\hline LPG & 12429 & 47,3 & 587,9 & 17,2 & 17,2 & 0,995 & 36,9 & 1 & 36,9 \\
\hline & & & & & & & & Toplam $\mathrm{CO}_{2}$ & 250,9 \\
\hline $\begin{array}{c}\mathrm{CH}_{4} \\
\text { Emisyonu }\end{array}$ & $\begin{array}{l}\text { Yakit } \\
\text { Tüketimi } \\
\text { (t) }\end{array}$ & $\begin{array}{l}\text { Değişim } \\
\text { Faktörü } \\
\text { (TJ/Gg) }\end{array}$ & $\begin{array}{c}\text { Enerji Tüketimi } \\
\quad(\mathrm{TJ}) \\
\mathrm{C}=\mathrm{A} \times \mathrm{B} \times 10^{-3}\end{array}$ & $\begin{array}{l}\text { Emisyon } \\
\text { Faktörü } \\
(\mathrm{tC} / \mathrm{TJ})\end{array}$ & $\begin{array}{c}\text { Emisyon İçeriği } \\
(\mathrm{Gg}) \\
\mathrm{E}=\mathrm{C} \times \mathrm{D} \times 10^{-3}\end{array}$ & $\begin{array}{l}\text { Oksitlenme } \\
\text { Yüzdesi } \\
(\%)\end{array}$ & $\begin{array}{c}\text { Emisyon Miktar1 } \\
(\mathrm{Gg})\end{array}$ & $\begin{array}{c}\text { Küresel Isınma } \\
\text { Potansiyeli }\end{array}$ & $\begin{array}{c}\text { Eşdeğer } \\
\mathrm{CO}_{2} \\
\left(\mathrm{Gg} \mathrm{CO}_{2}\right) \\
\mathrm{I}=\mathrm{G} \times \mathrm{H}\end{array}$ \\
\hline Benzin & 4756 & 44,3 & 210,7 & 33 & 0,007 & - & 0,007 & 21 & 0,15 \\
\hline Motorin & 61184 & 43,0 & 2630,7 & 3,9 & 0,010 & - & 0,010 & 21 & 0,22 \\
\hline LPG & 12429 & 47,3 & 587,9 & 62 & 0,036 & - & 0,036 & 21 & 0,77 \\
\hline & & & & & & & & Toplam $\mathrm{CH}_{4}$ & 1,1 \\
\hline $\mathrm{N}_{2} \mathrm{O}$ & Yakit & Değişim & Enerji Tüketimi & Emisyon & Emisyon İçeriği & Oksitlenme & Emisyon Miktar1 & Küresel Isınma & Eşdeğer \\
\hline Emisyonu & $\begin{array}{l}\text { Tüketimi } \\
(\mathrm{t})\end{array}$ & $\begin{array}{l}\text { Faktörü } \\
(\mathrm{TJ} / \mathrm{Gg})\end{array}$ & $\begin{array}{c}(\mathrm{TJ}) \\
\mathrm{C}=\mathrm{A} \times \mathrm{B} \times 10^{-3}\end{array}$ & $\begin{array}{l}\text { Faktörü } \\
(\mathrm{tC} / \mathrm{TJ})\end{array}$ & $\begin{array}{c}(\mathrm{Gg}) \\
\mathrm{E}=\mathrm{C} \times \mathrm{D} \times 10^{-3}\end{array}$ & $\begin{array}{c}\text { Yüzdesi } \\
(\%)\end{array}$ & $(\mathrm{Gg})$ & Potansiyeli & $\begin{array}{c}\mathrm{CO}_{2} \\
\left(\mathrm{Gg} \mathrm{CO}_{2}\right) \\
\mathrm{I}=\mathrm{G} \times \mathrm{H}\end{array}$ \\
\hline Benzin & 4756 & 44,3 & 210,7 & 3,2 & 0,0007 & - & 0,0007 & 310 & 0,21 \\
\hline Motorin & 61184 & 43,0 & 2630,7 & 3,9 & 0,0103 & - & 0,0103 & 310 & 3,18 \\
\hline LPG & 12429 & 47,3 & 587,9 & 0,2 & 0,0001 & - & 0,0001 & 310 & 0,04 \\
\hline & & & & & & & & Toplam $\mathrm{N}_{2} \mathrm{O}$ & 3,4 \\
\hline & & & & & & Toplam & leğer $\mathrm{CO}_{2}$ Emisy & $\overline{\mathrm{Gg} \mathrm{CO}}$ & 255,5 \\
\hline
\end{tabular}


Tablo 2. 2016 y1lı Mart-Ekim döneminde emisyon hesap tablosu

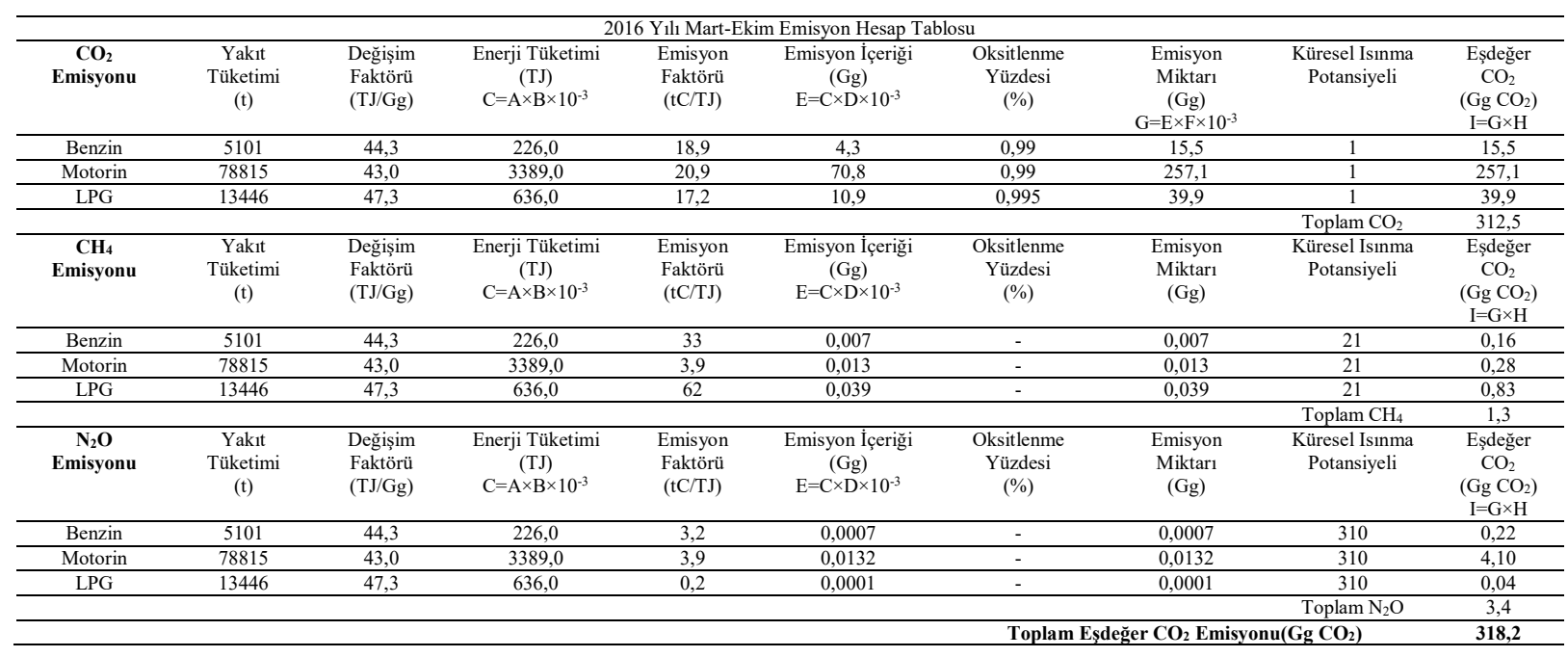

Tablo 3. 2017 y1lı Mart-Ekim döneminde emisyon hesap tablosu

\begin{tabular}{|c|c|c|c|c|c|c|c|c|c|}
\hline \multicolumn{10}{|c|}{2017 Yll Mart-Ekim Emisyon Hesap Tablosu } \\
\hline $\begin{array}{c}\mathrm{CO}_{2} \\
\text { Emisyonu }\end{array}$ & $\begin{array}{l}\text { Yakit } \\
\text { Tüketimi } \\
\text { (t) }\end{array}$ & $\begin{array}{l}\text { Değişim } \\
\text { Faktörü } \\
(\mathrm{TJ} / \mathrm{Gg})\end{array}$ & $\begin{array}{c}\text { Enerji Tüketimi } \\
(\mathrm{TJ}) \\
\mathrm{C}=\mathrm{A} \times \mathrm{B} \times 10^{-3}\end{array}$ & $\begin{array}{l}\text { Emisyon } \\
\text { Faktörü } \\
\text { (tC/TJ) }\end{array}$ & $\begin{array}{c}\text { Emisyon İçeriği } \\
(\mathrm{Gg}) \\
\mathrm{E}=\mathrm{C} \times \mathrm{D} \times 10^{-3}\end{array}$ & $\begin{array}{l}\text { Oksitlenme } \\
\text { Yüzdesi } \\
(\%)\end{array}$ & $\begin{array}{c}\text { Emisyon } \\
\text { Miktar1 } \\
(\mathrm{Gg}) \\
\mathrm{G}=\mathrm{E} \times \mathrm{F} \times 10^{-3}\end{array}$ & $\begin{array}{l}\text { Küresel Isinma } \\
\text { Potansiyeli }\end{array}$ & $\begin{array}{c}\text { Eşdeğer } \\
\mathrm{CO}_{2} \\
\left(\mathrm{Gg} \mathrm{CO}_{2}\right) \\
\mathrm{I}=\mathrm{G} \times \mathrm{H}\end{array}$ \\
\hline Benzin & 5417 & 44,3 & 240,0 & 18,9 & 4,5 & 0,99 & 16,5 & 1 & 16,5 \\
\hline Motorin & 119305 & 43,0 & 5130,1 & 20,9 & 107,2 & 0,99 & 389,2 & 1 & 389,2 \\
\hline$\overline{\text { LPG }}$ & 13498 & 47,3 & 638,5 & 17,2 & 11,0 & 0,995 & 40,1 & 1 & 40,1 \\
\hline & & & & & & & & Toplam $\mathrm{CO}_{2}$ & 445,7 \\
\hline $\mathrm{CH}_{4}$ & Yakit & Değişim & Enerji Tüketimi & Emisyon & Emisyon İçeriği & Oksitlenme & Emisyon & Küresel Isınma & Eşdeğer \\
\hline Emisyonu & $\begin{array}{l}\text { Tüketimi } \\
\text { (t) }\end{array}$ & $\begin{array}{l}\text { Faktörü } \\
(\mathrm{TJ} / \mathrm{Gg})\end{array}$ & $\begin{array}{c}(\mathrm{TJ}) \\
\mathrm{C}=\mathrm{A} \times \mathrm{B} \times 10^{-3}\end{array}$ & $\begin{array}{l}\text { Faktörü } \\
(\mathrm{tC} / \mathrm{TJ})\end{array}$ & $\begin{array}{c}(\mathrm{Gg}) \\
\mathrm{E}=\mathrm{C} \times \mathrm{D} \times 10^{-3}\end{array}$ & $\begin{array}{c}\text { Yüzdesi } \\
(\%)\end{array}$ & $\begin{array}{l}\text { Miktar1 } \\
(\mathrm{Gg})\end{array}$ & Potansiyeli & $\begin{array}{c}\mathrm{CO}_{2} \\
\left(\mathrm{Gg} \mathrm{CO}_{2}\right) \\
\mathrm{I}=\mathrm{G} \times \mathrm{H}\end{array}$ \\
\hline Benzin & 5417 & 44,3 & 240,0 & 33 & 0,008 & - & 0,008 & 21 & 0,17 \\
\hline Motorin & 119305 & 43,0 & 5130,1 & 3,9 & 0,020 & - & 0,020 & 21 & 0,42 \\
\hline LPG & 13498 & 47,3 & 638,5 & 62 & 0,040 & - & 0,040 & 21 & 0,83 \\
\hline & & & & & & & & Toplam $\mathrm{CH}_{4}$ & 1,4 \\
\hline $\mathrm{N}_{2} \mathrm{O}$ & Yakit & Değişim & Enerji Tüketimi & Emisyon & Emisyon İçeriği & Oksitlenme & Emisyon & Küresel Isınma & Eşdeğer \\
\hline Emisyonu & $\begin{array}{l}\text { Tüketimi } \\
\text { (t) }\end{array}$ & $\begin{array}{l}\text { Faktörü } \\
(\mathrm{TJ} / \mathrm{Gg})\end{array}$ & $\begin{array}{c}(\mathrm{TJ}) \\
\mathrm{C}=\mathrm{A} \times \mathrm{B} \times 10^{-3}\end{array}$ & $\begin{array}{l}\text { Faktörü } \\
(\mathrm{tC} / \mathrm{TJ})\end{array}$ & $\begin{array}{c}(\mathrm{Gg}) \\
\mathrm{E}=\mathrm{C} \times \mathrm{D} \times 10^{-3}\end{array}$ & $\begin{array}{c}\text { Yüzdesi } \\
(\%)\end{array}$ & $\begin{array}{l}\text { Miktar1 } \\
(\mathrm{Gg})\end{array}$ & Potansiyeli & $\begin{array}{c}\mathrm{CO}_{2} \\
\left(\mathrm{Gg} \mathrm{CO}_{2}\right) \\
\mathrm{I}=\mathrm{G} \times \mathrm{H}\end{array}$ \\
\hline Benzin & 5417 & 44,3 & 240,0 & 3,2 & 0,0008 & - & 0,0008 & 310 & 0,24 \\
\hline Motorin & 119305 & 43,0 & 5130,1 & 3,9 & 0,0200 & - & 0,0200 & 310 & 6,20 \\
\hline LPG & 13498 & 47,3 & 638,5 & 0,2 & 0,0001 & - & 0,0001 & 310 & 0,04 \\
\hline & & & & & & & & Toplam $\mathrm{N}_{2} \mathrm{O}$ & 6,5 \\
\hline & & & & & & Toplam & $\mathrm{er} \mathrm{CO}_{2} \mathrm{Emis}$ & $\overline{\mathrm{Gg} \mathrm{CO}}$ & 453,6 \\
\hline
\end{tabular}

Tablo 4. 2018 y1lı Mart-Ekim döneminde emisyon hesap tablosu

\begin{tabular}{|c|c|c|c|c|c|c|c|c|c|}
\hline \multicolumn{10}{|c|}{2018 Y1l1 Mart-Ekim Emisyon Hesap Tablosu } \\
\hline $\begin{array}{c}\mathrm{CO}_{2} \\
\text { Emisyonu }\end{array}$ & $\begin{array}{l}\text { Yakıt } \\
\text { Tüketimi } \\
\text { (t) }\end{array}$ & $\begin{array}{l}\text { Değişim } \\
\text { Faktörü } \\
(\mathrm{TJ} / \mathrm{Gg})\end{array}$ & $\begin{array}{c}\text { Enerji Tüketimi } \\
\text { (TJ) } \\
\mathrm{C}=\mathrm{A} \times \mathrm{B} \times 10^{-3}\end{array}$ & $\begin{array}{l}\text { Emisyon } \\
\text { Faktörü } \\
\text { (tC/TJ) }\end{array}$ & $\begin{array}{c}\text { Emisyon İçeriği } \\
(\mathrm{Gg}) \\
\mathrm{E}=\mathrm{C} \times \mathrm{D} \times 10^{-3}\end{array}$ & $\begin{array}{l}\text { Oksitlenme } \\
\text { Yüzdesi } \\
(\%)\end{array}$ & $\begin{array}{c}\text { Emisyon } \\
\text { Miktar1 } \\
(\mathrm{Gg}) \\
\mathrm{G}=\mathrm{E} \times \mathrm{F} \times 10^{-3} \\
\end{array}$ & $\begin{array}{l}\text { Küresel Isınma } \\
\text { Potansiyeli }\end{array}$ & $\begin{array}{c}\text { Eşdeğer } \\
\mathrm{CO}_{2} \\
\left(\mathrm{Gg} \mathrm{CO}_{2}\right) \\
\mathrm{I}=\mathrm{G} \times \mathrm{H} \\
\end{array}$ \\
\hline Benzin & 5580 & 44,3 & 247,2 & 18,9 & 4,7 & 0,99 & 17,0 & 1 & 17,0 \\
\hline Motorin & 154900 & 43,0 & 6660,7 & 20,9 & 139,2 & 0,99 & 505,3 & 1 & 505,3 \\
\hline LPG & 13601 & 47,3 & 643,3 & 17,2 & 11,1 & 0,995 & 40,4 & 1 & 40,4 \\
\hline & & & & & & & & Toplam $\mathrm{CO}_{2}$ & 562,7 \\
\hline $\begin{array}{c}\mathrm{CH}_{4} \\
\text { Emisyonu }\end{array}$ & $\begin{array}{c}\text { Yakıt } \\
\text { Tüketimi } \\
\text { (t) }\end{array}$ & $\begin{array}{l}\text { Değişim } \\
\text { Faktörü } \\
(\mathrm{TJ} / \mathrm{Gg})\end{array}$ & $\begin{array}{c}\text { Enerji Tüketimi } \\
\text { (TJ) } \\
\mathrm{C}=\mathrm{A} \times \mathrm{B} \times 10^{-3}\end{array}$ & $\begin{array}{l}\text { Emisyon } \\
\text { Faktörü } \\
(\mathrm{tC} / \mathrm{TJ})\end{array}$ & $\begin{array}{c}\text { Emisyon İçeriği } \\
(\mathrm{Gg}) \\
\mathrm{E}=\mathrm{C} \times \mathrm{D} \times 10^{-3}\end{array}$ & $\begin{array}{l}\text { Oksitlenme } \\
\text { Yüzdesi } \\
(\%)\end{array}$ & $\begin{array}{l}\text { Emisyon } \\
\text { Miktar1 } \\
(\mathrm{Gg})\end{array}$ & $\begin{array}{c}\text { Küresel Isınma } \\
\text { Potansiyeli }\end{array}$ & $\begin{array}{c}\text { Eşdeğer } \\
\mathrm{CO}_{2} \\
\left(\mathrm{Gg} \mathrm{CO}_{2}\right) \\
\mathrm{I}=\mathrm{G} \times \mathrm{H}\end{array}$ \\
\hline Benzin & 5580 & 44,3 & 247,2 & 33 & 0,008 & - & 0,008 & 21 & 0,17 \\
\hline Motorin & 154900 & 43,0 & 6660,7 & 3,9 & 0,026 & - & 0,020 & 21 & 0,55 \\
\hline LPG & 13601 & 47,3 & 643,3 & 62 & 0,040 & - & 0,040 & 21 & 0,84 \\
\hline & & & & & & & & Toplam $\mathrm{CH}_{4}$ & 1,6 \\
\hline $\begin{array}{c}\mathrm{N}_{2} \mathrm{O} \\
\text { Emisyonu }\end{array}$ & $\begin{array}{c}\text { Yakit } \\
\text { Tüketimi } \\
\text { (t) }\end{array}$ & $\begin{array}{l}\text { Değişim } \\
\text { Faktörü } \\
(\mathrm{TJ} / \mathrm{Gg})\end{array}$ & $\begin{array}{c}\text { Enerji Tüketimi } \\
\text { (TJ) } \\
\mathrm{C}=\mathrm{A} \times \mathrm{B} \times 10^{-3}\end{array}$ & $\begin{array}{l}\text { Emisyon } \\
\text { Faktörü } \\
(\mathrm{tC} / \mathrm{TJ})\end{array}$ & $\begin{array}{c}\text { Emisyon İçeriği } \\
(\mathrm{Gg}) \\
\mathrm{E}=\mathrm{C} \times \mathrm{D} \times 10^{-3}\end{array}$ & $\begin{array}{l}\text { Oksitlenme } \\
\text { Yüzdesi } \\
(\%)\end{array}$ & $\begin{array}{c}\text { Emisyon } \\
\text { Miktar1 } \\
\text { (Gg) }\end{array}$ & $\begin{array}{c}\text { Küresel Isınma } \\
\text { Potansiyeli }\end{array}$ & $\begin{array}{c}\text { Eşdeğer } \\
\mathrm{CO}_{2} \\
\left(\mathrm{Gg} \mathrm{CO}_{2}\right) \\
\mathrm{I}=\mathrm{G} \times \mathrm{H}\end{array}$ \\
\hline Benzin & 5580 & 44,3 & 247,2 & 3,2 & 0,0008 & - & 0,0008 & 310 & 0,25 \\
\hline Motorin & 154900 & 43,0 & 6660,7 & 3,9 & 0,0260 & - & 0,0260 & 310 & 8,05 \\
\hline LPG & 13601 & 47,3 & 643,3 & 0,2 & 0,0001 & - & 0,0001 & 310 & 0,04 \\
\hline & & & & & & & & Toplam $\mathrm{N}_{2} \mathrm{O}$ & 8,3 \\
\hline & & & & & & Toplam & ger $\mathrm{CO}_{2}$ Emisy & $\left(\mathrm{Gg} \mathrm{CO}_{2}\right)$ & 572,5 \\
\hline
\end{tabular}


Tablo 5. 2019 y1lı Mart-Ekim döneminde emisyon hesap tablosu

\begin{tabular}{|c|c|c|c|c|c|c|c|c|c|}
\hline \multicolumn{10}{|c|}{2019 Yılı Mart-Ekim Emisyon Hesap Tablosu } \\
\hline $\begin{array}{c}\mathrm{CO}_{2} \\
\text { Emisyonu }\end{array}$ & $\begin{array}{l}\text { Yakit } \\
\text { Tüketimi } \\
\text { (t) }\end{array}$ & $\begin{array}{l}\text { Değgişim } \\
\text { Faktörü } \\
(\mathrm{TJ} / \mathrm{Gg})\end{array}$ & $\begin{array}{c}\text { Enerji Tüketimi } \\
\text { (TJ) } \\
\mathrm{C}=\mathrm{A} \times \mathrm{B} \times 10^{-3}\end{array}$ & $\begin{array}{l}\text { Emisyon } \\
\text { Faktörü } \\
\text { (tC/TJ) }\end{array}$ & $\begin{array}{c}\text { Emisyon İçeriği } \\
(\mathrm{Gg}) \\
\mathrm{E}=\mathrm{C} \times \mathrm{D} \times 10^{-3}\end{array}$ & $\begin{array}{l}\text { Oksitlenme } \\
\text { Yüzdesi } \\
(\%)\end{array}$ & $\begin{array}{c}\text { Emisyon } \\
\text { Miktar1 } \\
(\mathrm{Gg}) \\
\mathrm{G}=\mathrm{E} \times \mathrm{F} \times 10^{-3}\end{array}$ & $\begin{array}{c}\text { Küresel Isınma } \\
\text { Potansiyeli }\end{array}$ & $\begin{array}{c}\text { Eşdeğer } \\
\mathrm{CO}_{2} \\
\left(\mathrm{Gg} \mathrm{CO}_{2}\right) \\
\mathrm{I}=\mathrm{G} \times \mathrm{H}\end{array}$ \\
\hline Benzin & 6177 & 44,3 & 273,6 & 18,9 & 5,2 & 0,99 & 18,8 & 1 & 18,8 \\
\hline Motorin & 85628 & 43,0 & 3682,0 & 20,9 & 77,0 & 0,99 & 279,3 & 1 & 279,3 \\
\hline$\overline{\mathrm{LPG}}$ & 14246 & 47,3 & 673,8 & 17,2 & 11,6 & 0,995 & 42,3 & 1 & 42,3 \\
\hline & & & & & & & & Toplam $\mathrm{CO}_{2}$ & 340,4 \\
\hline $\begin{array}{c}\mathrm{CH}_{4} \\
\text { Emisyonu }\end{array}$ & $\begin{array}{c}\text { Yakıt } \\
\text { Tüketimi } \\
\text { (t) }\end{array}$ & $\begin{array}{l}\text { Değişim } \\
\text { Faktörü } \\
(\mathrm{TJ} / \mathrm{Gg})\end{array}$ & $\begin{array}{c}\text { Enerji Tüketimi } \\
\text { (TJ) } \\
\mathrm{C}=\mathrm{A} \times \mathrm{B} \times 10^{-3}\end{array}$ & $\begin{array}{l}\text { Emisyon } \\
\text { Faktörü } \\
(\mathrm{tC} / \mathrm{TJ})\end{array}$ & $\begin{array}{c}\text { Emisyon İçeriği } \\
(\mathrm{Gg}) \\
\mathrm{E}=\mathrm{C} \times \mathrm{D} \times 10^{-3}\end{array}$ & $\begin{array}{l}\text { Oksitlenme } \\
\text { Yüzdesi } \\
\text { (\%) }\end{array}$ & $\begin{array}{l}\text { Emisyon } \\
\text { Miktar1 } \\
(\mathrm{Gg})\end{array}$ & $\begin{array}{c}\text { Küresel Isınma } \\
\text { Potansiyeli }\end{array}$ & $\begin{array}{c}\text { Eşdeğer } \\
\mathrm{CO}_{2} \\
\left(\mathrm{Gg} \mathrm{CO}_{2}\right) \\
\mathrm{I}=\mathrm{G} \times \mathrm{H}\end{array}$ \\
\hline Benzin & 6177 & 44,3 & 273,6 & 33 & 0,009 & - & 0,009 & 21 & 0,19 \\
\hline Motorin & 85628 & 43,0 & 3682,0 & 3,9 & 0,014 & - & 0,014 & 21 & 0,30 \\
\hline$\overline{\mathrm{LPG}}$ & 14246 & 47,3 & 673,8 & 62 & 0,042 & - & 0,042 & 21 & 0,88 \\
\hline & & & & & & & & Toplam $\mathrm{CH}_{4}$ & 1,4 \\
\hline $\begin{array}{c}\mathrm{N}_{2} \mathrm{O} \\
\text { Emisyonu }\end{array}$ & $\begin{array}{c}\text { Yakıt } \\
\text { Tüketimi } \\
\text { (t) }\end{array}$ & $\begin{array}{l}\text { Değişim } \\
\text { Faktörü } \\
(\mathrm{TJ} / \mathrm{Gg})\end{array}$ & $\begin{array}{c}\text { Enerji Tüketimi } \\
\quad(\mathrm{TJ}) \\
\mathrm{C}=\mathrm{A} \times \mathrm{B} \times 10^{-3}\end{array}$ & $\begin{array}{c}\text { Emisyon } \\
\text { Faktörü } \\
(\mathrm{tC} / \mathrm{TJ})\end{array}$ & $\begin{array}{c}\text { Emisyon İçeriği } \\
(\mathrm{Gg}) \\
\mathrm{E}=\mathrm{C} \times \mathrm{D} \times 10^{-3}\end{array}$ & $\begin{array}{l}\text { Oksitlenme } \\
\text { Yüzdesi } \\
(\%)\end{array}$ & $\begin{array}{l}\text { Emisyon } \\
\text { Miktarı } \\
(\mathrm{Gg})\end{array}$ & $\begin{array}{c}\text { Küresel Isınma } \\
\text { Potansiyeli }\end{array}$ & $\begin{array}{c}\text { Eşdeğer } \\
\mathrm{CO}_{2} \\
\left(\mathrm{Gg} \mathrm{CO}_{2}\right) \\
\mathrm{I}=\mathrm{G} \times \mathrm{H}\end{array}$ \\
\hline Benzin & 6177 & 44,3 & 273,6 & 3,2 & 0,0009 & - & 0,0009 & 310 & 0,27 \\
\hline Motorin & 85628 & 43,0 & 3682,0 & 3,9 & 0,0144 & - & 0,0144 & 310 & 4,45 \\
\hline$\overline{\text { LPG }}$ & 14246 & 47,3 & 673,8 & 0,2 & 0,0001 & - & 0,0001 & 310 & 0,04 \\
\hline & & & & & & & & Toplam $\mathrm{N}_{2} \mathrm{O}$ & 4,8 \\
\hline & & & & & & Topla & $\mathrm{CO}_{2} \mathrm{Em}$ & $\left.\mathrm{Gg} \mathrm{CO}_{2}\right)$ & 346,5 \\
\hline
\end{tabular}

Tablo 6. 2020 y1lı Mart-Ekim döneminde emisyon hesap tablosu

\begin{tabular}{|c|c|c|c|c|c|c|c|c|c|}
\hline \multicolumn{10}{|c|}{2020 Y1lı Mart-Ekim Emisyon Hesap Tablosu } \\
\hline $\begin{array}{c}\mathrm{CO}_{2} \\
\text { Emisyonu }\end{array}$ & $\begin{array}{l}\text { Yakit } \\
\text { Tüketimi } \\
\text { (t) }\end{array}$ & $\begin{array}{l}\text { Değgişim } \\
\text { Faktörü } \\
(\mathrm{TJ} / \mathrm{Gg})\end{array}$ & $\begin{array}{c}\text { Enerji Tüketimi } \\
\text { (TJ) } \\
\mathrm{C}=\mathrm{A} \times \mathrm{B} \times 10^{-3}\end{array}$ & $\begin{array}{l}\text { Emisyon } \\
\text { Faktörü } \\
\text { (tC/TJ) }\end{array}$ & $\begin{array}{c}\text { Emisyon İçeriği } \\
(\mathrm{Gg}) \\
\mathrm{E}=\mathrm{C} \times \mathrm{D} \times 10^{-3}\end{array}$ & $\begin{array}{l}\text { Oksitlenme } \\
\text { Yüzdesi } \\
(\%)\end{array}$ & $\begin{array}{c}\text { Emisyon } \\
\text { Miktarı } \\
(\mathrm{Gg}) \\
\mathrm{G}=\mathrm{E} \times \mathrm{F} \times 10^{-3} \\
\end{array}$ & $\begin{array}{c}\text { Küresel Isınma } \\
\text { Potansiyeli }\end{array}$ & $\begin{array}{c}\text { Eşdeğer } \\
\mathrm{CO}_{2} \\
\left(\mathrm{Gg} \mathrm{CO}_{2}\right) \\
\mathrm{I}=\mathrm{G} \times \mathrm{H} \\
\end{array}$ \\
\hline Benzin & 5774 & 44,3 & 255,8 & 18,9 & 4,8 & 0,99 & 17,5 & 1 & 17,5 \\
\hline Motorin & 96976 & 43,0 & 4170,0 & 20,9 & 87,2 & 0,99 & 316,4 & 1 & 316,4 \\
\hline LPG & 12303 & 47,3 & 581,9 & 17,2 & 10,0 & 0,995 & 36,5 & 1 & 36,5 \\
\hline & & & & & & & & Toplam $\mathrm{CO}_{2}$ & 370,4 \\
\hline $\begin{array}{c}\mathrm{CH}_{4} \\
\text { Emisyonu }\end{array}$ & $\begin{array}{l}\text { Yakıt } \\
\text { Tüketimi } \\
\text { (t) }\end{array}$ & $\begin{array}{l}\text { Değişim } \\
\text { Faktörü } \\
(\mathrm{TJ} / \mathrm{Gg})\end{array}$ & $\begin{array}{c}\text { Enerji Tüketimi } \\
\text { (TJ) } \\
\mathrm{C}=\mathrm{A} \times \mathrm{B} \times 10^{-3}\end{array}$ & $\begin{array}{l}\text { Emisyon } \\
\text { Faktörü } \\
(\mathrm{tC} / \mathrm{TJ})\end{array}$ & $\begin{array}{c}\text { Emisyon İçeriği } \\
(\mathrm{Gg}) \\
\mathrm{E}=\mathrm{C} \times \mathrm{D} \times 10^{-3}\end{array}$ & $\begin{array}{l}\text { Oksitlenme } \\
\text { Yüzdesi } \\
\text { (\%) }\end{array}$ & $\begin{array}{l}\text { Emisyon } \\
\text { Miktar1 } \\
(\mathrm{Gg})\end{array}$ & $\begin{array}{c}\text { Küresel Isınma } \\
\text { Potansiyeli }\end{array}$ & $\begin{array}{c}\text { Eşdeğer } \\
\mathrm{CO}_{2} \\
\left(\mathrm{Gg} \mathrm{CO}_{2}\right) \\
\mathrm{I}=\mathrm{G} \times \mathrm{H}\end{array}$ \\
\hline Benzin & 5774 & 44,3 & 255,8 & 33 & 0,008 & - & 0,008 & 21 & 0,18 \\
\hline Motorin & 96976 & 43,0 & 4170,0 & 3,9 & 0,016 & - & 0,016 & 21 & 0,34 \\
\hline LPG & 12303 & 47,3 & 581,9 & 62 & 0,036 & - & 0,036 & 21 & 0,76 \\
\hline & & & & & & & & Toplam $\mathrm{CH}_{4}$ & 1,3 \\
\hline $\begin{array}{c}\mathrm{N}_{2} \mathrm{O} \\
\text { Emisyonu }\end{array}$ & $\begin{array}{l}\text { Yakıt } \\
\text { Tüketimi } \\
\text { (t) }\end{array}$ & $\begin{array}{l}\text { Değişim } \\
\text { Faktörü } \\
(\mathrm{TJ} / \mathrm{Gg})\end{array}$ & $\begin{array}{c}\text { Enerji Tüketimi } \\
\text { (TJ) } \\
\mathrm{C}=\mathrm{A} \times \mathrm{B} \times 10^{-3}\end{array}$ & $\begin{array}{l}\text { Emisyon } \\
\text { Faktörü } \\
(\mathrm{tC} / \mathrm{TJ})\end{array}$ & $\begin{array}{c}\text { Emisyon İçeriği } \\
(\mathrm{Gg}) \\
\mathrm{E}=\mathrm{C} \times \mathrm{D} \times 10^{-3}\end{array}$ & $\begin{array}{l}\text { Oksitlenme } \\
\text { Yüzdesi } \\
\text { (\%) }\end{array}$ & $\begin{array}{l}\text { Emisyon } \\
\text { Miktar1 } \\
(\mathrm{Gg})\end{array}$ & $\begin{array}{c}\text { Küresel Isınma } \\
\text { Potansiyeli }\end{array}$ & $\begin{array}{c}\text { Eşdeğer } \\
\mathrm{CO}_{2} \\
\left(\mathrm{Gg} \mathrm{CO}_{2}\right) \\
\mathrm{I}=\mathrm{G} \times \mathrm{H}\end{array}$ \\
\hline Benzin & 5774 & 44,3 & 255,8 & 3,2 & 0,0008 & - & 0,0008 & 310 & 0,25 \\
\hline Motorin & 96976 & 43,0 & 4170,0 & 3,9 & 0,0163 & - & 0,0163 & 310 & 5,04 \\
\hline LPG & 12303 & 47,3 & 581,9 & 0,2 & 0,0001 & - & 0,0001 & 310 & 0,04 \\
\hline & & & & & & & & Toplam $\mathrm{N}_{2} \mathrm{O}$ & 5,3 \\
\hline & & & & & & Toplam & $\mathrm{CO}_{2}$ Emisy & $\left(\mathrm{Gg} \mathrm{CO}_{2}\right)$ & 377,0 \\
\hline
\end{tabular}

Mart-Ekim ayları boyunca eşdeğer $\mathrm{CO}_{2}$ miktarı 2020 yılında 377,0 Gg, 2019 yılında 346,5 Gg, 2018 yılında 572,5 Gg, 2017 y1lında 453,6 Gg, 2016 yılında 318,2 Gg, 2015 y1lında 255,5 Gg'dır. Eşdeğer $\mathrm{CO}_{2}$ miktarı 2015-2018 yılları arası yükselen bir eğilimde seyrederken 2019'da azalma göstermiştir. 2020 yılında eşdeğer $\mathrm{CO}_{2}$ miktarı ise 2019'dan 31,5 $\mathrm{Gg} \mathrm{CO}_{2}$ farkla yeniden artış göstermektedir (Şekil 8).

2020 yılında Covid-19 salgını sebebiyle tüm ülkelerde olduğu gibi ülkemizde de bazı tedbirler alınmıştır. Bu tedbirler insan hareketliliğini azaltma dolayısıyla bulaşma riskini minimuma indirme amacıyla alınmıştır. $\mathrm{Bu}$ nedenle ulaşım faaliyeti diğer hayati faaliyetler gibi bu tedbirlerden etkilenmiştir. İnsan hareketliliği azaldığından araç kullanımı dolayısıyla akaryakıt tüketimi 
azalmıştır. Akaryakıt tüketiminin azalması Şekil 8'de görüldüğü üzere 2020 Mart-Ekim arasında eşdeğer $\mathrm{CO}_{2}$ emisyonunun $2015^{\prime}$ ten bu yana aynı aylarda oluşan eşdeğer $\mathrm{CO}_{2}$ emisyonlarının ortalaması alındığında ortalamadan daha düşük olduğu görülecektir. 2019 yılı Mart-Ekim aylarında (bu aylar ticaretin ve hareketliliğin en çok olduğu aylardır) geçmiş diğer yıllardaki $\mathrm{CO}_{2}$ emisyon trendini bozduğu yine Şekil 8'de görmek mümkündür.

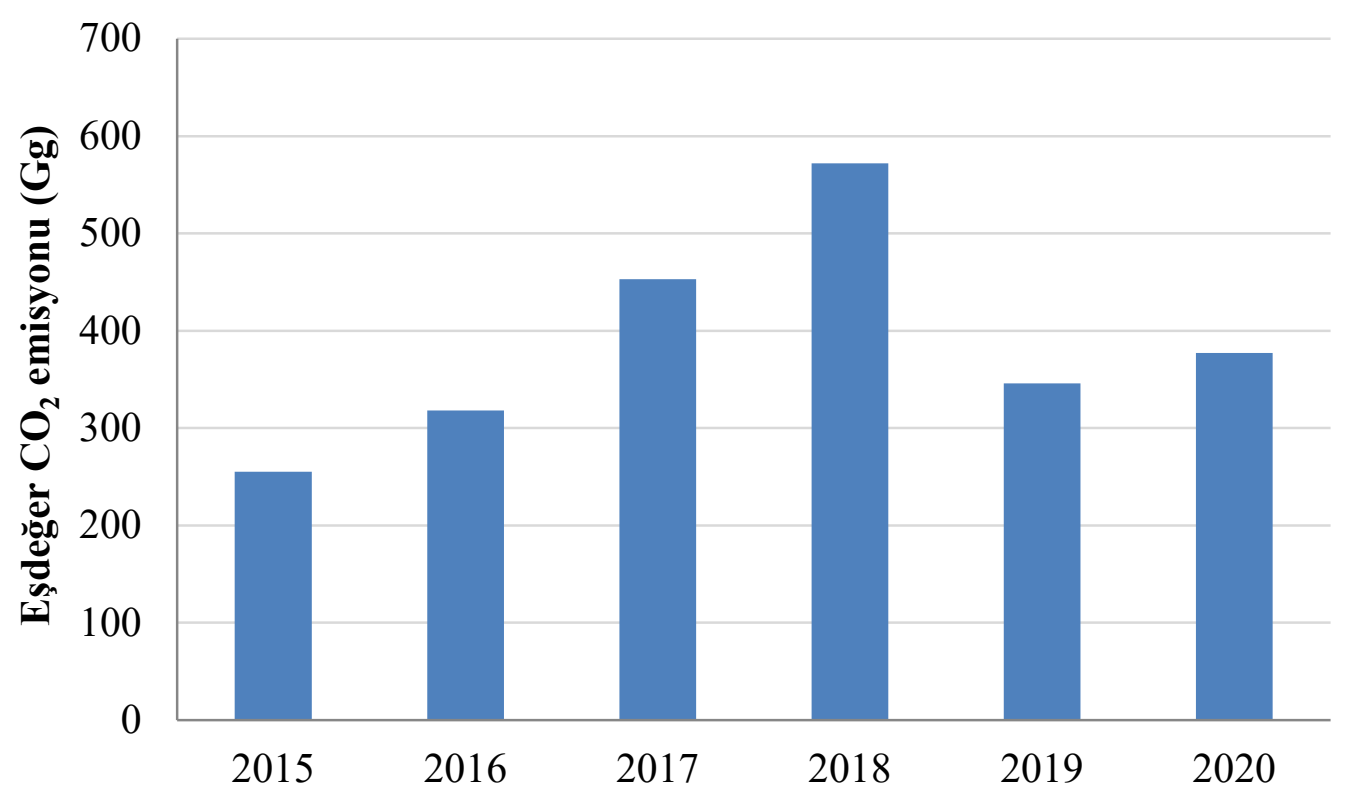

Şekil 8. Mart-Ekim döneminde yıllara göre eşdeğer $\mathrm{CO}_{2}(\mathrm{Gg})$ emisyon değerleri

Şekil 9'da Covid-19 salgınının küresel olarak ve 11 ülkenin her birinde günlük $\mathrm{CO}_{2}$ emisyonları üzerindeki etkileri, 1 Ocak ile 30 Haziran 2019 ve 2020 arasındaki gölgeli farklarla yansıtılmaktadır. 2020'nin ilk altı ayında, en belirgin düşüş ABD'de (-338,3 $\mathrm{Mt} \mathrm{CO}_{2},-\%$ 13,3), ardından EU27 ve Birleşik Krallık (-205,7 Mt CO $2,-\%$ 12,7), Hindistan (-205,2 $\mathrm{Mt} \mathrm{CO}_{2}$, - \% 15,4) ve Çin (-187,2 Mt $\left.\mathrm{CO}_{2},-\% 3,7\right)$, Japonya (-43,1 $\mathrm{Mt} \mathrm{CO}_{2},-\%$ 7,5), Rusya (-40,5 $\mathrm{Mt} \mathrm{CO}_{2},-\%$ 5,3) ve Brezilya'da (-25,9 Mt $\mathrm{CO}_{2},-\%$ 12.0) kademeli şekilde yaşanmıştır. Çin emisyonlarının ani, büyük ve erken düşüşü, pandeminin ilk vakalarının ortaya çıkması ve ülkenin Mart ayında kademeli olarak gevşetilen katı kilitleme önlemlerine karşılık gelmektedir. Ancak Çin'in $\mathrm{CO}_{2}$ emisyonları daha sonra hızla geri kazanılmıştır. $\mathrm{CO}_{2}$ emisyonlarındaki azalmanın başlıca nedeni kara taşımacılığı sektörü (-\% 18.6) ve yurtiçi (-\% 35.8) ve uluslararası havacılıktır (-\% 52.4) (Liu ve ark., 2020).

Covid-19 pandemi döneminde hava kalitesi değişimini ölçmek amacıyla 2020 yılında yapılan bir çalışmada, Hindistan'ın Kalküta şehri 12 bölgeye ayrılmış ve bu bölgelerde atmosferik $\mathrm{CO}_{2}$ emisyon takibi yapılmıştır. $2020 \mathrm{CO}_{2}$ konsantrasyon verileri ile $2019 \mathrm{CO}_{2}$ konsantrasyon verilerinin karşılaştırılması sonucunda $2020 \mathrm{CO}_{2}$ emisyonlarının 2019 yılına oranla ciddi düşüş gösterdiği tespit edilmiştir. Sealdah bölgesinde \% 45,37'lere varan düşüş yaşanırken ve Kalküta'da ortalama \%39 azalma olduğu gözlenmiştir. $\mathrm{Bu} \mathrm{CO}_{2}$ konsantrasyonundaki düşüşlerin sebebi olarak pandemi 
döneminde ulaşım yoğunluğunun azalması, endüstri ve turizmin sektörlerinin yavaşlaması ve faaliyetlerinin durma noktasona gelmesi gösterilmekte olup dolayısıyla fosil yakıt tüketiminin büyük ölçüde azalmasına bağlanmıştır (Mitra ve ark., 2020).
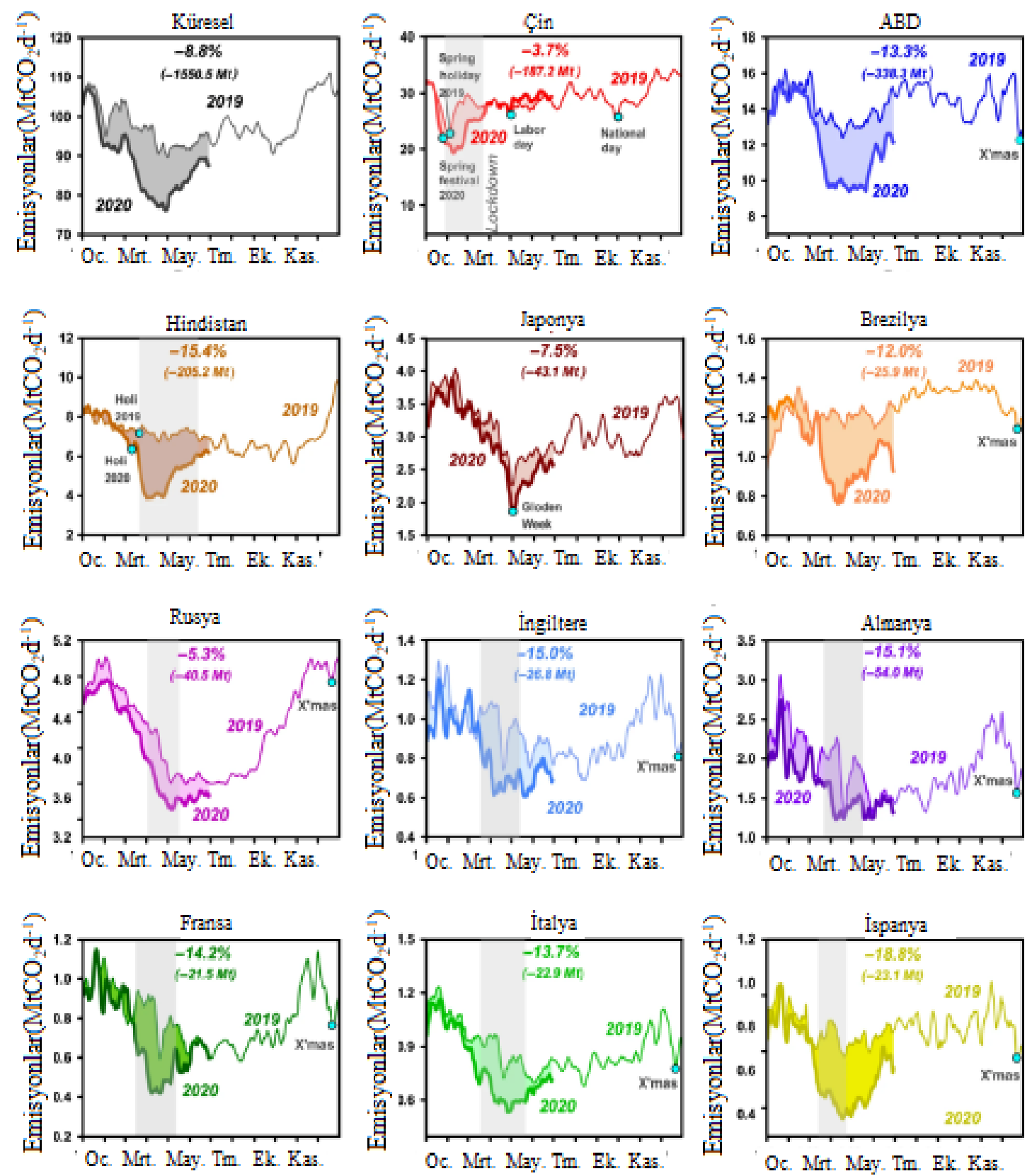

Şekil 9. Ülkelerin Günlük $\mathrm{CO}_{2}$ emisyonları (2019-2020 karşılaştırmalı) (Liu ve ark., 2020)

Saadat ve arkadaşlarının 2020 yılında yayınlanan araştırmasında; Korona virüsün yayılmasını kısıtlamak için alınan önlemler nedeniyle New York'taki hava kirliliği seviyelerinin 2019 yılının 2020 yılına kıyasla neredeyse \% 50 düştüğü belirtilmiştir. Çin'de 2019'un son üç ayından bu yana büyük elektrik santrallerinde kömür kullanımı \% 40 oranında azaltıldığından hava kirliliği emisyon verilerinin 2020 yılının başlangıcında \% 25'lik bir düşüş olduğundan bahsetmektedir (Saadat ve ark., 2020). 
Lau ve arkadaşlarının yaptığı diğer bir çalışmada da Korona virüsün çevre üzerindeki diğer etkilerinden biri de kömür tüketimindeki gözle görülür düşüş olduğundan bahsetmektedir. Bu olayın Çin'deki hava kirleticilerinde büyük ölçekli bir düşüşe katkıda bulunduğunu, $\mathrm{CO}_{2}, \mathrm{CO}$ ve azot oksitler gibi havadaki kirletici maddelerin sayısı da azaldığını savunmaktadır (Lau ve ark., 2020).

McCloskey ve Heymann'ın (2020) yaptığı çalışmada hava kirliliği emisyonlarındaki bu düşüşün ne kadar süreceğinin belli olmadığı ve sonunda karbonu emisyonu ve kirletici emisyonları geri döndüğünde, sanki ara dönem (Pandemi dönemi) hiç yaşanmamış ve bugün gördügümüz değişikliklerin kalıcı bir etkisi olmayacağını savunmaktadır.

Şahin ve Erensü (2020), pandemi sırasında ekonomik faaliyetin azalmasının sera gazı emisyonlarını ve hava kirliliğini azaltması herhangi bir kalıcı etki yaratmadığını düşünmektedir. Pandemi, fosil yakıtların kullanıldığı ekonomik ve günlük yaşam faaliyetleri karbonsuz bir hale getirildiğinde hem hava kirliliğinin hem de iklim değişikliğine neden olan emisyonların azalacağına ve bu neden-sonuç ilişkisinin hemen görünür hale geldiğine dair bir deney işlevi görme imkanı sağladığına dair düşünce ortaya koymuştur. Araştırmacılar, pandemi döneminde olduğu gibi iklim krizinde de acil müdahale gerektiğini ve önlem alınması gerekliliğini belirtmişlerdir.

Sancar ve Bostanc1 (2020), literatür bulgularının Covid-19 pandemi sürecinde bile ülkelerin hedeflenen karbon emisyonu seviyelerini beklenen düzeyde azaltmadığını gösterdiği, pandemi sürecinde karbon emisyonunun azalmasının doğaya ve hava kalitesine etkilerini somut şekilde gösterdiğini, ülkelerin gelecek kararlarında bu bilgiyi dikkate almalarının sağlıklı bir gelecek için umut oluşturup oluşturmayacağının bilinmediğini öne sürmüştür.

\section{Sonuçlar ve Öneriler}

Çalışma sonucunda, Nevşehir İli’nde 2015-2020 yılları arasında Mart-Ekim ayları arasında tüketilen akaryakıt miktarı ile $\mathrm{CO}_{2}$ salınımının doğru orantılı olduğu, yapılan hesaplamalar sonucunda eşdeğer $\mathrm{CO}_{2}(\mathrm{Gg})$ miktarlarındaki değişimden görülmektedir. Akaryakıtların motorlarda yanma olayı sonrasında açığa çıkardıkları emisyon miktarının yakıt türüne göre önemli derecede farklılık gösterdiği anlaşılmaktadır. 2019'da Nevşehir'de olduğu gibi ülkemizde de genel olarak akaryakıt tüketimi azalmıştır. Ülkelerin gelişmişlik düzeyleri doğrultusunda ticari aksiyonları ve sosyoekonomik durumları, ulaşım gereksinimlerine olan ihtiyacı belirlediği gibi konfor talebini de yansıtır. Özellikle trafiğe çıkan araç sayısının artması ve henüz alternatif yakıtların (elektrik gibi) geniş kullanım alanı bulamaması sebebiyle 2019 ve 2020 yılları boyunca hava kirliliği oluşturan kirleticilerde ciddi oranda azalmalar olduğu göz ardı edilmemelidir. IPCC'nin tüm ülkeler için varsayılan olarak belirlediği emisyon faktörleri de dikkate alındığında bu araştırma kapsamında 
Nevşehir il geneli özelinde hava kalitesini kötü yönde etkileyen sera gazı emisyonlarına en yüksek katkıyı veren yakıt sıralamasının motorin > benzin > LPG şeklinde olduğu görülmektedir.

Nevşehir İl genelinde trafik büyükşehirlerimize kıyasla az olsa da, kentin Türkiye’nin tam orta noktasında bölgeler arasında nakliyenin merkezinde yer alması nedeniyle önemli bir konumu da vardır. Akdeniz Bölgesi ile İç Anadolu üzerinden Karadeniz ve Marmara bölgesine kadar uzanan güzergahta, kamyon ve tır gibi ticari araçların çok sayıda geçiş yaptığı bir trafik bağlantı noktasında olması sebebiyle emisyon miktarına katkıda motorinin, neden ön planda olduğunu açıklar bir durumdur.

Kentlerde hava kirliliğine neden olan fosil yakıtla çalışan ve ulaşımda kullanılan motorlu araçlar aynı zamanda iklim değişikliğine neden olan karbon emisyonlarının en önemli kaynaklarından biri durumundadır. Küresel ısınma ve iklim değişikliğini hızlandırıcı etkiye sahip olan sera gazlarının motorlu taşıtlarda enerji üretimi sonucu açığa çıktığını düşündüğümüzde, trafik kaynaklı ortaya çıkan sera gazlarını azaltmak için önemli birkaç seçeneğimiz olduğunu görmekteyiz. Birinci seçenek, fosil yakıtlı motorların yanma teknolojilerinin hali hazırda bulunan teknolojiye göre daha az sera gazı açığa çıkartmasını sağlamaktır. Bu seçeneğin kısa periyotta etkili olduğu söylenebilir ancak kümülatif olarak değerlendirdiğimizde küresel ısınmaya katkısı son derece kısıtlı kalacaktır. Bir başka seçenek ise trafikte seyreden motorlu araç sayılarını azaltmaktır. Bunun için toplu taşıma kullanmak, bisiklet kullanmak vs. gibi çözümler karşımıza çıkmaktadır. Fakat bu çözümlere insanları ikna etmek oldukça zordur. Bireysel ulaşım imkanlarının artmasıyla konforlu yaşamanın getirdiği kültürel değişim ve tüketim alışkanlıkları, insanların gelecekte toplu taşıma kullanmasının önündeki en büyük engeller arasındadır. İnsanları toplu taşımaya ikna etmek için motorlu araç vergilerini yükseltmek yine kısa vadede etkili fakat negatif bir çözüm olduğundan toplumsal sıkıntılar doğabileceği göz ardı edilmemelidir. $\mathrm{Bu}$ durumda halihazırda gündemdeki seçenek olan fosil yakıtlı motorlu kara taşıtlarının terk edilmesi ve bunun yerine elektrikli araçların kullanımının teşvik edilmesi ve tüketicilerin bu konuda bilinçlendirilmesi son derece önemli hale gelmektedir. Elektrikli kara taşıtları teknoloji ve üretiminin ülke yönetimi ve karar verici kurumlar tarafından teşvik edilmesi ve gelecek nesillere taşınması konusunda bilgilendirme faaliyetlerinin sürdürülmesi bu konuda iyi bir hamle olacaktır. Bir yandan elektrikli araç arzı yapılırken bir yandan da elektrikli araç kullanımında vergi indirimi yapılması da pozitif etki yapacağından, kullanıcıların fosil yakıtlı araçları terk etmesi dolaylı olarak desteklenecektir.

Ulaşımda motorlu taşıtlardan kaynaklanan sera gazlarını azaltmada yerel yönetimlerin alacağı tedbirlerin başarılı olabilmesi ve sürdürülebilir temiz havanın sağlanabilmesi ancak araç teknolojisindeki hızlı gelişimle birlikte trafikte dolaşan araçların yeni motor teknolojisine sahip olmaları ile mümkündür. $\mathrm{Bu}$ yeni teknolojiyle geliştirilen araçların emisyon salınım miktarlarının düşük olması da oldukça önemlidir. Burada, araçların aerodinamik yapısının geliştirilmesi, lastik 
yapılarının geliştirilmesi, trafik sinyalizasyonlarının geliştirilmesi, kentin ve yolların hava akımını sağlayacak ve trafiği sıkıştırmayacak şekilde planlanması, yakıt alternatiflerinin araştırılması ve teşvik edilmesi (doğalgaz ve biyodizel vs.) gibi küresel çapta etkinliği test edilen yöntemler sürdürülebilir ve döngüsel ekonominin bir parçası olarak uygulanabilir. Bu tür uygulamaların hem ulusal hem de yerel bazda hayata geçirilmesi kentlerimizin hava kalitesini artırmasında etkili olacaktır.

\section{Teșekkür}

Bu araştırma, NEVÜ Fen Bilimleri Enstitüsü, Çevre Mühendisliği Anabilim Dalı Programı kapsamında sürdürülen "Nevşehir İli karayolu ulaşımından kaynaklanan sera gazı emisyonunun değerlendirilmesi", adlı yüksek lisans tez çalışmasının bir bölümünden üretilmiş olup veri tedariki için Enerji Piyasası Düzenleme Kurumu ve Çevre Şehircilik İl Müdürlüğüne teşekkür ederiz.

\section{Yazarların Katkısı}

Tüm yazarlar çalışmaya eşit katkıda bulunmuştur.

\section{Çıkar Çatışması Beyanı}

Yazarlar arasında herhangi bir çıkar çatışması bulunmamaktadır.

\section{Araştırma ve Yayın Etiği Beyanı}

Yapılan çalışmada araştırma ve yayın etiğine uyulmuştur.

\section{Kaynaklar}

Ali, H., Y1lmaz, G., Fareed, Z., Shahzad, F., and Ahmad, M. (2021). Impact of novel coronavirus (COVID19) on daily routines and air environment: evidence from Turkey. Air Quality, Atmosphere \& Health, 14(3), 381-387.

Cabré, A., Marinov, I., and Leung, S. (2015). Consistent global responses of marine ecosystems to future climate change across the IPCC AR5 earth system models. Climate Dynamics, 45(5), 1253-1280.

Canitez, F. (2019). Pathways to sustainable urban mobility in developing megacities: A socio-technical transition perspective. Technological Forecasting and Social Change, 141, 319-329.

Change, I. (2006). IPCC guidelines for national greenhouse gas inventories 2006. Institute for Global Environmental Strategies, Hayama, Kanagawa, Japan.

Change, I.C. (2007). The physical science basis. In: Cambridge Univ. Press. 
Change, I.P.o.C., and I.P.o.C.W.G. (1990). Scientific Assessment of Climate Change: The Policymakers' Summary of the Report of Working Group I to the Intergovernmental Panel on Climate Change. World Meteorological Organization/United Nations Environment Programme

Council, N.R. (2009). Informing decisions in a changing climate. National Academies Press.

Cüce, H., Kalıpcı, E., Taş B., ve Yılmaz M. (2020). Rakım farklılığı nedeniyle oluşan meteorolojik değişimlerin su kalitesine olan etkilerinin CBS ile değerlendirilmesi: Morfolojik olarak farklı iki göl için bir karşılaştırma. Karadeniz Fen Bilimleri Dergisi, 10(1), 1-26.

Demirel, H., ve Ateş, A. (2018). Sapanca Gölü çevresinde karayolu trafiğinden kaynaklanan hava kirleticilerinin emisyon envanteri. Sakarya Üniversitesi Fen Bil. Enstitüsü Dergisi, 22(2), 150-158.

Dulkadiroğlu, H. (2018). Türkiye'de elektrik üretiminin sera gazı emisyonları açısından incelenmesi. Niğde Ömer Halisdemir Üniversitesi Mühendislik Bilimleri Dergisi, 7(1), 67-74.

Geçer, E., Şentürk, İ., ve Büyükgüngör, H. (2019). Yeşil bina tasarımında su ve enerji yönetimi üzerine uygulama örneği. Gümüşhane Üniversitesi Fen Bil. Enstitüsü Dergisi, 9(2), 332-343.

Intergovernmental Panel on Climate Change, IPCC. (2013). AR5: Climate Change 2013: The Physical Science Basis, Technical Summary. New York, s.35

Kalıpcı, E., ve Başer, V. (2019). Coğrafi Bilgi Sistemi (CBS) ve hava kalitesi verileri kullanılarak Türkiye'nin hava kirliliğinin değerlendirilmesi. Karadeniz Fen Bilimleri Dergisi, 9(2), 377-389.

Kreith, F., and Berger, S. (1999). Mechanical Engineering Handbook. (Ed.) Frank Kreith Boca Raton: CRC Press LLC, In: Intelligent Transportation Systems.

Mach, K. J., Mastrandrea, M. D., Bilir, T. E., and Field, C. B. (2016). Understanding and responding to danger from climate change: the role of key risks in the IPCC AR5. Climatic Change, 136(3-4), 427-444.

McCloskey, B., and Heymann, D. L. (2020). SARS to novel coronavirus-old lessons and new lessons. Epidemiology \& Infection, 148.

Mercan, M., ve Karakaya, E. (2013). Sera Gazı Salımının Azaltımında Alternatif Politikaların Ekonomik Maliyetlerinin İncelenmesi: Türkiye İçin Genel Denge Analizi. Erciyes Üniversitesi İktisadi ve İdari Bilimler Fakültesi Dergisi, (42), 123-159.

Mitra, A., Chaudhuri, T. R., Mitra, A., Pramanick, P., Zaman, S., Mitra, A., ... and Zaman, S. (2020). Impact of Covid-19 related shutdown on atmospheric carbon dioxide level in the city of Kolkata. Parana Journal of Science and Education, 6(3), 84-92.

Lau, H., Khosrawipour, V., Kocbach, P., Mikolajczyk, A., Schubert, J., Bania, J., \& Khosrawipour, T. (2020). The positive impact of lockdown in Wuhan on containing the Covid-19 outbreak in China. Journal of travel medicine, 27(3), a037.

Le Quéré, C., Jackson, R.B., Jones, M.W., Smith, A.J., Abernethy, S., Andrew, R.M., De-Gol, A.J., Willis, D.R., Shan, Y., and Canadell, J.G. (2020). Temporary reduction in daily global $\mathrm{CO}_{2}$ emissions during the Covid-19 forced confinement. Nature Climate Change, 10, 647-653.

Liu, Z., Ciais, P., Deng, Z., Lei, R., Davis, S.J., Feng, S., Zheng, B., Cui, D., Dou, X., and Zhu, B. (2020). Near-real-time monitoring of global $\mathrm{CO}_{2}$ emissions reveals the effects of the Covid-19 pandemic. Nature communications, 11, 1-12.

Saadat, S., Rawtani, D., and Hussain, C. M. (2020). Environmental perspective of Covid-19, Science of The Total Environment, 728 (2020), 138870.

Sancar, O., ve Bostancı S. (2020). Covid-19 Pandemi Sürecinde Karbon Emisyonu Üzerine Bir Tartışma, Iğdır Üniversitesi Sos. Bil. Der., 269-292

Şahin, Ü., ve Erensü, S. (2020). Covid-19 Pandemisini ve İklim Krizini Birlikte Okumak. Mercator Politika Notu.Sabancı Üniversitesi İPM.

URL-1: https://www.globalchange.gov/climate-change. Climate Science Special Report (Erişim Tarihi: 20 Ocak 2021).

URL-2: https://www.iea.org/countries/turkey. World Energy Balances 2020 (Erişim Tarihi: 22 Şubat 2021).

URL-3: https://www.kgm.gov.tr (Erişim Tarihi: 23 Aralık 2020). 